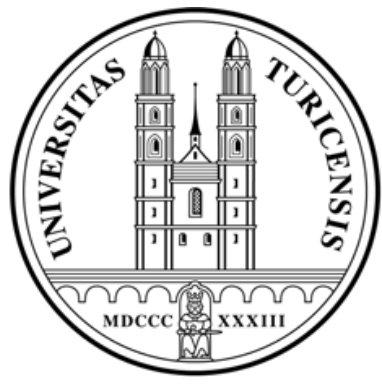

Institute for Empirical Research in Economics

University of Zurich

Working Paper Series

ISSN 1424-0459

Working Paper No. 209

The Role of Direct Democracy and Federalism in Local Power

Bruno S. Frey and Alois Stutzer

October 2004 


\title{
THE ROLE OF DIRECT DEMOCRACY AND FEDERALISM IN LOCAL POWER
}

\author{
Bruno S. Frey* and Alois Stutzer** \\ (University of Zurich) \\ October, 2004
}

Prof. Dr. Dr. h.c. mult. Bruno S. Frey

Dr. Alois Stutzer

Institute for Empirical Research in Economics

University of Zurich

Bluemlisalpstrasse 10

$\mathrm{CH}-8006$ Zurich

Switzerland

and

CREMA - Center for Research in Economics, Management and the Arts

* Phone: +41-44-634 3731, Fax: +41-44-634 4907, E-mail: bsfrey@iew.unizh.ch

** Phone: +41-44-634 3729, Fax: +41-44-634 4907, E-mail: astutzer@iew.unizh.ch 


\title{
The Role of Direct Democracy and Federalism in Local Power
}

\begin{abstract}
Alienation to politics weakens political competition and can undermine the acceptance and legitimacy of democracy as a political system. Governance and representation problems at the local level cause part of citizens' lack of power and political alienation. Citizens have local power if they can influence the political process so that its outcomes are closer to their preferences and if they feel to be effective in the political sphere. In order to increase citizens' local power, we emphasize the role of institutions of local governance. Local democratic governance is concerned about the relationship between citizens and local government institutions, political representatives and officials. This relationship is fundamentally shaped by the federal structure of a nation's government and by the scope and depth of citizens' participation possibilities in the political process. (129 words)
\end{abstract}

JEL classification: D70, D71, D72, H10, H77

Keywords: collective decision-making, constitutional design, constitutional economics, direct democracy, fiscal federalism, local governance, local power, participation 


\section{Contents}

\section{Local Power and Citizens' Preferences}

1 Introduction 1

2 Citizens' Lack of Local Power 2

\section{Institutional Preconditions for Local Power}

3 A New Democratic Federalism for Local Problems 4

3.1 Comparative Analysis of Federalism 4

$\begin{array}{lll}3.2 & \text { FOCJ: Beyond Traditional Federalism } & 11\end{array}$

3.3 FOCJ in the Future and in the Past 17

4 Direct Democratic Participation Rights 21

4.1 Direct Democracy Against Politicians' Cartel 23

4.2 Referendums as a Process 28

4.3 Empirical Evidence on the Consequences of Direct Democracy 30

4.4 Arguments against and Counter-Arguments for Referendums 37

5 Interaction between Federal and Democratic Institutions 43

\section{Issues for Institutional Reform}

6 Reforming Local Governance $\quad 45$

6.1 Implementation of FOCJ 45

6.2 Precondition in Society for Direct Democracy 47

6.3 Gradual Introduction of Direct Democracy 48

7 Concluding Remarks $\quad 51$

$\begin{array}{ll}\text { References } & 54\end{array}$ 


\section{Local Power and Citizens' Preferences}

\section{Introduction}

A large fraction of the citizenry is alienated to politics: it cannot understand current politics and does not think of itself to be able to take an active role in it. This is a serious problem as it weakens political competition and thus the citizens' control of political actors in a democracy. As a consequence, citizens may be disappointed by the actual consequences of democratic decisions, which in turn can undermine the acceptance and legitimacy of democracy as a political system.

This diagnosis is supposed to hold at the international, the national, as well as the local level. ${ }^{1}$ Here, we emphasize governance and representation problems at the local level that lead to a lack of power for the citizens.

We think of citizens having local power if they can influence the political process so that its outcomes are closer to their preferences and if they feel to be effective in the political sphere. This is close to the World Bank's understanding of empowerment as a process of "increasing the capacity of individuals or groups to make choices and to transform those into desired actions and outcomes" (World Bank 2004). However, our understanding of local power goes beyond outcomes and includes citizens' preferences about the processes of decision-making itself. It includes citizens' feelings of autonomy and self-determination that are directly contributing to their subjective well-being. The latter aspect is called procedural utility. ${ }^{2}$

In order to increase citizens' local power, we emphasize the role of institutions of local governance. Local democratic governance is concerned about the relationship between citizens and local government institutions, political representatives and officials. This relationship is fundamentally shaped by the federal structure of a nation's government and by the scope and depth of citizens' participation possibilities in the political process.

In this contribution, we first present empirical evidence for the low level of perceived political influence and the low level of political discourse in Europe at the beginning of the new

\footnotetext{
${ }^{1}$ For a discussion in international governance see Stutzer and Frey (2004).

${ }^{2}$ Procedural utility is introduced and discussed for a wide range of institutions in Frey et al. (2004).
} 
century (section 2). In section 3, we discuss theoretical arguments and empirical evidence on the role of fiscal federalism in local power and propose a new democratic federalism to improve weaknesses of existing forms of decentralized democratic systems prevalent in many countries. In order to obtain the benefits of fiscal decentralization, it is critically important that citizens can exercise their voice option. Section 4 argues for the favorable role of direct democracy in giving citizens a direct say in local politics. The interaction between federal and democratic institutions and their mutual enforcement is discussed in section 5. Section 6 studies the precondition in society for the (gradual) introduction of participatory political institutions. Section 7 offers concluding remarks.

\section{Citizens' Lack of Local Power}

How is the constitutional choice of local governance affecting citizens' local power? While we discuss many arguments and emphasize the positive role of fiscal federalism and direct democracy, the question has ultimately to be addressed empirically. There is a sizeable empirical literature on the working and consequences of fiscal federalism (e.g. Oates 1999, Inman and Rubinfeld 2000, Kirchgässner 2001), as well as of direct democracy (see section 4). Many of these findings are discussed in the text and can be understood as citizens getting a better or worse outcome from the political process as a result of their high or low local power. As a starting point, we identify the level of perceived influence of European citizens. Concepts in political science discuss people's feeling of political efficacy (Lane 1959). Internal efficacy refers to people's experience of "being capable of acting effectively in the political realm" (Finkel 1985: 289, see also Niemi et al. 1991). What people think about their political influence can also be captured in surveys. Multiple indicators have been proposed (e.g. Balch 1974, Craig and Maggiotto 1982). Here, comparable data are studied from the first wave of the European Social Survey conducted in 2002. Three questions capture citizens' perceived understanding of politics, their effectiveness and their involvement.

a) Understanding of politics. People are asked "How often does politics seem so complicated that you can't really understand what is going on?" They respond on a five step scale ranging from "never", "seldom", "occasionally", "regularly" to "frequently". For 22 European countries, figure 1 presents representative results for the fraction of people who report that they regularly or frequently cannot understand what is going on in politics. Overall, a large fraction of the citizenry in Europe perceives politics as too complicated. There are eight countries, including Spain, in which more than 40 percent report that politics is too 
complicated. The fraction is highest in Greece with 63 percent. On the other end of the league table, there is Norway where only 25 percent report that politics is too complicated for them.

[Figure 1 about here]

b) Taking an active role in politics. In another question of the European Social Survey, people are asked "Do you think that you could take an active role ${ }^{3}$ in a group involved with political issues?" The categories for their answer are "definitely not", "probably not", "not sure either way", "probably" and "definitely". Figure 2 shows the percentage of people in each of 22 European countries that thinks that they can probably not or definitely not take an active role in politics. A clear majority of people thinks that they could not take an active role. In 19 out of 22 countries, the fraction is above 50 percent, being highest in Spain (79 percent). Local power according to this indicator is highest in Denmark where only 35 percent see no possibility to take an active role in politics. ${ }^{4}$

[Figure 2 about here]

c) Political discourse. Citizens' involvement in political discourse is measured by the question: "How often would you say you discuss ${ }^{5}$ politics and current affairs?" People answer either by "every day", "several times a week", “once a week", "several times a month", "once a month", "less often" or "never". Figure 3 shows that there is a large variation of the fraction of people who discusses politics less often than once a month. While it is only 15 percent in Switzerland, it is approximately half the population in Greece. Spain belongs to the group of countries where more than 45 percent of the citizens rarely discuss political issues.

\footnotetext{
3 "Take an active role": in the sense of participate in discussion/debates and decisions.

${ }^{4}$ While the results are similar to those on understanding politics for most countries, there is one big difference: Greece. Many people in Greece think that they could take an active role while for most of them politics is too complicated. We check whether a coding mistake in the European Social Survey data created this puzzling finding.

5 "Discuss" in the sense of discussing with friends or chatting about politics or policies at for example one's workplace or in bus queues to relative strangers.
} 
[Figure 3 about here]

In sum, the survey results indicate that there are many people in Europe who are alienated from the democratic political process despite Europe's commitment to democracy. However, the results also show sizeable differences across countries. We hypothesize that part of the variation is due to differences in local governance. For example, it is suggestive that citizens in Switzerland, the only country in Europe that gives citizens extended direct democratic participation rights at all levels of government, have relatively high local power. A look at the rankings indicates that citizens in Switzerland belong to the top third with regard to local power and discuss politics more often than people in any other European country.

\section{Institutional Preconditions for Local Power}

\section{A New Democratic Federalism for Local Problems}

The federal structure of a country or nation involves basic constitutional decisions about the relationship between the central government and sub-national governments along a number of different dimensions. These include i) the partition of a single national jurisdiction into states, Laender, provinces, districts or cantons, and communes, ii) the assignment of policy competences and political responsibility to the different levels, iii) the allocation of the power to tax to the different jurisdictions, iv) the choice of rules for democratic participation in the jurisdictions, and v) the rules applied to change the federal constitution of a country or nation.

\subsection{Comparative Analysis of Federalism}

The Economic Theory of Federalism yields one clear and overriding result: a federal (i.e. decentralized) state is superior to a centralized one in the sense that it fulfils the demands of the citizens more effectively. A federal constitution that endows the federal units with sufficient decision-making rights and taxing power has four major advantages over a unitary state. 


\section{Major advantages of a fiscally decentralized state}

a) More flexible politics. In all societies, citizens differ widely in their demand for services provided by the state. These differences in demand are not only the result of heterogeneous tastes due to differences in tradition, culture, language etc, but also of unequal economic conditions. The latter are caused by, for example, leads or lags in the general business cycle and, of course, special structural conditions such as differences in infrastructure, unemployment, the concentration of particular industries etc. These differences in the demand for public services must be met by differentiated supply policies if citizens' preferences are to be fulfilled. Federal sub-units are best able to meet this challenge. The politicians in charge are better endowed with information about the local requirements. They have the incentives to provide these services according to the preferences of the citizens because they are directly accountable for the local policy and their reelection depends on the satisfaction of the voters they represent. ${ }^{6}$ In contrast, centralized states tend to produce unitary policies which do less respond to differences in local demands. ${ }^{7}$

b) More efficient provision of public services. The efficiency of the public sector is extremely important due to the very large size of today's public sectors in terms of the share of government in national income, the proportion of public officials in total employment, the dependence of a substantial portion of the population on income redistributed by government (e.g. in the form of subsidies, social security and old age pensions) and, of course, the many resources that go into tax collection. In federally-organized states, efficiency is enhanced by the mechanism of exit and entry. Individuals and firms which are not satisfied with the balance between the supply and cost of public services may move to jurisdictions where this balance is more favorable. Exit and entry thus establish competition among the various local suppliers of public services, giving them a strong incentive to be efficient. The exit/entry-

\footnotetext{
${ }^{6}$ It could be argued that locally elected politicians in central states face also incentives to care for local preferences. However, in many countries, the members of the national parliament are only partly, or not at all, elected in local precincts. In the Federal Republic of Germany, for instance, a substantial share of the members of the Bundestag are not elected by winning in a particular precinct but because they are placed on a list which is controlled by the party they belong to. Moreover, in national parliaments, a local delegates' accountability is low as he is only one of several hundred parliamentarians.

${ }^{7}$ The argument that competition between jurisdictions generates incentives for self-interested governments to follow citizens preferences and to effectively spend public funds has been profoundly discussed by Brennan und Buchanan (1980).
} 
mechanism does not depend on the full mobility of individuals or firms (there are, of course, costs of moving); it suffices if some such mobility is induced (in analogy to the marginal traders leading to equilibrium prices on normal goods markets). Indeed, spatial competition between jurisdictions in a federal system mimics competition among firms for the supply of private goods and services (Tiebout, 1956).

c) More innovation. In a federal system, innovations in public goods supply or taxation can be implemented first in those local units where the conditions are ideal for success. Moreover, a particular local unit finds it less risky to undertake innovations in public goods supply or taxation because the effects are limited and can be better observed and controlled. If the innovation is unsuccessful, not much is lost. However, if it proves to be successful, it will be quickly adopted by other jurisdictions and eventually the entire nation. For this Hayekian process to take place, the innovators must reap at least some of the benefits. This is much more the case when the innovation starts from a clearly-defined local jurisdiction where the success (or failure) can be clearly attributed to the respective politicians and governments.

d) More extensive participation. A central aspect of federalism are the extended possibilities of democratic political decision-making. A decentralized country with small jurisdictions offers scope for participatory democracy (for a discussion in the context of federalism see Inman and Rubinfeld 2000). Democratic participation at the local level generates the incentives necessary to bring about the efficient outcomes of fiscal federalism described above. In addition to this instrumental value, participation is also valued in its own right ${ }^{8}$ and citizens gain procedural utility from living in an environment that grants political participation possibilities (Stutzer and Frey 2004).

Political participation possibilities contribute to what Lane (1988) calls procedural goods of democracy. These contain e.g. dignity goods, such as self-respect, feeling of personal control or understanding and public resonance. Democracy can further provide utility if it offers relief from procedural pain (e.g. fear, embarrassment or humiliation) or if it directly generates

\footnotetext{
${ }^{8}$ Political philosophers and proponents of participatory democracy have argued for a long time that participation in self-governance provides people with a feeling of competence, control and satisfaction (e.g. Barber 1984, Mansbridge 1983, Pateman 1970 and Thompson 1970). A procedural value of participation - in a non-consequential sense - is also emphasized in democratic theory (e.g. Dahl 1956, Sartori 1987 and Scharpf 1970).
} 
intrinsic pleasure, for example, by facing and meeting a challenge or by expressing oneself (Lane 1988: 179-185, see also Lane 2000, chapter 13). ${ }^{9}$

Moreover, political participation might even have an educational function. The political discussion induced by political participation generates a common understanding for different political opinions and positions. This strengthens the social contract based on consensus, and motivates people to act beyond narrow self-interest (Bohnet and Frey 1994). Participation possibilities are thus considered an important source of perceived procedural fairness shaping individual behavior. It has, for example, been shown that, with more extensive democratic participation rights, people have higher tax morale and evade taxes less (Frey 1997).

This argument links to civic virtue, which mirrors the intrinsic motivation of the citizens and the politicians to contribute to public interest. It has by now been well established that civic virtue with both citizens and politicians is an indispensable factor for a successful democracy (see, e.g., Brennan and Hamlin 2000, or Putnam 1993, 2000). ${ }^{10}$

As these arguments are not considered to be in the core of the economic theory of federalism, we briefly add some comments on empirical research. A critical review of the early crosscountry evidence on size and participation is provided by Dahl and Tufte (1973). They report evidence supporting the participation theorists' predictions that citizens in small communities are more aware of local politics, know more political facts and perceive higher potential effectiveness than citizens in large communities. Recent research on participation and perceived effectiveness focuses on specific institutions rather than community size as such. For example, citizens' experience with direct democracy in US states is found to form positive attitudes about their abilities to influence what government does (Bowler and Donovan 2002).

We are not aware of any research that relates perceived political influence to the degree of fiscal federalism. ${ }^{11}$ Such an analysis could build on recent comparative indices on fiscal federalism (Curzon Price and Garello 2003). In figure 4, we present scatter plots and bivariate regression results for the indicators of local power across Europe presented in section 2. On

\footnotetext{
${ }^{9}$ Lane (1988) argues that "[d]emocratic theory makes inadequate provision for procedural goods other than distributive justice“(p. 186).

${ }^{10}$ How democratic federalism has the potential to crowd in civic virtue is discussed in Eichenberger and Frey (2002).
} 
the horizontal axis, the degree of fiscal decentralization is measured on a scale from 0 to 5 , whereby 5 indicates high fiscal decentralization. Data is available for 14 countries of which 13 are included in the European Social Survey. ${ }^{12}$

[Figure 4 about here]

For all three indicators of political involvement, a correlation is measured that indicates a positive effect of fiscal decentralization on local power: In more fiscally decentralized nations (i) less people think that politics is too complicated, (ii) less people think that they could not take an active role in politics, and (iii) more people are engaged in political discourse. This seems a promising starting point for further research.

\section{Major challenges for a federal constitution}

In spite of these great advantages, federalism is not an ideal system. But there is no ideal system. Following the well-established Comparative Analysis of Institutions, it is fruitless to judge any existing system by a theoretical optimum. Rather, a comparison must be made with systems existing in reality. In the case of federalism, it is appropriate to compare it with a centralized state. From this point of view, it has often been alleged that a federal constitution is faced with four major problems:

a) Spillover effects. Spatial positive and negative externalities, produce systematic distortions in the allocation of publicly supplied goods and services. "Fiscal equivalence" (Olson 1969, Oates 1972) is not secured: some benefits of local public supply spill over to citizens of other jurisdictions who have not paid the corresponding tax cost (which induces under-supply); some costs are carried by citizens outside a particular jurisdiction (which induces oversupply). This cause for the distorted allocation of public services cannot be neglected. In reality, it has often be observed that such spillovers are substantial. Part of the fiscal crises of cities can be

\footnotetext{
${ }^{11}$ Related research studies the relationship between local autonomy and life satisfaction in an analysis across Swiss cantons. A positive partial correlation is estimated (Frey and Stutzer 2000).

${ }^{12}$ The countries included are the following with the fiscal decentralization score in parentheses: Switzerland (4.0), Denmark (3.0), Italy (3.0), Sweden (2.8), Germany (2.6), Poland (2.6), Norway (2.5), Hungary (2.5), Slovakia (2.4), Spain (2.3), Slovenia (2.2), Czech Republic (1.9), United Kingdom (1.8), France (1.7) and Republic of Ireland (1.3).
} 
attributed to that factor. An example is a cultural institution (like, e.g., a opera house) whose costs are carried by the local tax payers but whose benefits are enjoyed by many people living and paying taxes outside the city. Acknowledging that such positive and negative spillovers may be serious under many circumstances, we propose a solution: the size of the jurisdiction should correspond to the "geography of problems".

b) Smallness. In traditional federalism, jurisdictions are often too small to exploit economies of scale. Think, for example, of nuclear power plants or universities, which normally require heavy capital investments for a local jurisdiction (city, commune) to run efficiently. In our proposal for a new federalism, we are trying to confront the problem directly. We envisage flexible (functional) jurisdictions which are able to adjust to the lowest cost size.

c) Need for coordination. It is often claimed that federalism makes cooperation difficult or impossible. However, this is only part of the real problem. In federal states, cooperation among the various national sub-units emerges endogenously because it is obviously advantageous for all actors concerned. Moreover, it should be noted that coordination problems also exist within unitary states, in particular among the various national ministries whose competencies and interests overlap. Thus, a unitary state is neither a necessary nor sufficient condition for effective cooperation.

d) Redistribution of income. When a local unit tries to tax the rich in order to support the poor, the rich will leave and the poor will enter. The redistribution policy therefore cannot be maintained in a federalist state, but is only feasible in a unitary state. This argument has some truth in it. However, empirical evidence shows that federalist structures allow for a substantial amount of income redistribution (see, e.g., Gold 1991 for the US, Ashworth et al. 2002 for Belgium). An example is Switzerland where the (partly very small) 26 cantons together with about 3000 communities levy more than $80 \%$ of total income and capital taxes. Although each canton is free to set its own tax schedule, all cantons rely on progressive taxes and engage heavily in income redistribution (see Kirchgässner and Pommerehne 1996, Feld 2000). It seems that decentralization strengthens citizens' local ties thereby reducing mobility but increasing support for local redistribution. Moreover, quite a large amount of redistribution exists between rich and poor cantons. Nevertheless, the problem of redistribution in a decentralized governmental system has to be taken seriously. In our proposal for a new kind of federalism, we argue that this is one of the functions for which the national state is sometimes an appropriate jurisdiction. 
The previous considerations show that there are many advantages of decentralization and only few disadvantages. This does not mean that countries considered "federal" today fully exploit the advantages and provide citizens with strong local power. Rather there is scope for substantial reforms.

"Federal" countries exhibit vastly different extents of decentralization and of competencies attributed to lower levels of the governmental organization. For federalism to work in a satisfactory way and to sustain local power, there are two crucial conditions to be met:

First, the sub-units must have the power to tax citizens for the functions they perform. This forces them to balance the benefits and costs of government activities. At the same time, this gives the sub-units a certain degree of independence from the central government. This requirement is not met in most "federations". As a consequence, local politicians engage in widespread rent seeking activities with the central administration. They have to please the political decision-makers at the center to obtain funds. Once granted, they have few incentives not to spend them completely and to thus waste them, as such funds have the character of a "free good". The local politicians' rent seeking activities also encompass subsidies to cover budget deficits. Such an institutional landscape fosters fiscal irresponsibility at the local level. As this "irresponsibility" is a direct consequence of the high degree of centralization, it does not occur when the local politicians have the competence to balance revenues and expenditures in their own jurisdiction. If it turns out that they are incapable of doing so, the citizens will throw them out of office.

This points to the second crucial condition for a well-functioning federalism. The local politicians must be elected by the citizens of their jurisdictions, and not by a larger electorate, let alone being appointed by the central government. This requirement aligns the politicians' incentives with the wishes of the local population.

Most presently existing federal governments do not meet these two requirements, or do so only to a limited degree. For that reason, a new type of federalism is proposed, which seeks to strengthen the advantages and to overcome the disadvantages of federalism discussed above. 


\subsection{FOCJ: Beyond Traditional Federalism}

The federal units proposed here are named FOCJ according to their four essential characteristics: they are

- Functional $(F)$, i.e. the new political units extend over areas defined by the tasks to be fulfilled;

- Overlapping $(O)$, i.e. in line with the many different tasks (functions) there are corresponding governmental units extending over different geographical areas;

- Competing $(C)$, i.e. individuals and/or communities may choose to what governmental unit they want to belong, and they have political rights to express their preferences directly via initiatives and referenda;

- Jurisdictions $(J)$, i.e. the units established are governmental, they have enforcement power and can, in particular, levy taxes.

These functional, overlapping, and competing jurisdictions form a federal system of governments that is not dictated from above, but emerges from below as a response to citizens' preferences. For this to become reality, a fifth freedom has to be enacted, which in some way is the political counterpart to the four economic freedoms. It simply allows for such FOCJ. Such a fifth freedom requires a constitutional decision (see, e.g., Frey 1983, Mueller 1996) which ensures that the emergence of FOCJ is not blocked by existing jurisdictions such as direct competitors or higher level governments. Every citizen and community must have the right to directly appeal to the European Court if barriers to the competition between governments are established. The European Constitution must give the lowest political units (communities) a measure of independence so that they can engage in forming FOCJ. The citizens must be given the right to establish FOCJ by popular referenda, and political entrepreneurs must be supported and controlled by the institution of popular initiatives. The FOCJ themselves must have the right to levy taxes in order to finance the public services they provide.

The concept of FOCJ is based on theoretical propositions advanced in the economic theory of federalism. It nevertheless leads to a governmental system that is completely different to the one suggested in that literature. While the economic theory of federalism (see Oates 1991, or the various contributions on federalism in the Fall 1997 issue of the Journal of Economic 
Perspectives) analyzes the behavior of given political units at the different levels of government, FOCJ emerge in response to the 'geography of problems'.$^{13}$

FOCJ with their four main elements are now compared with existing federal institutions and theoretical concepts, pointing out both similarities and differences and the beneficial effects of FOCJ.

\section{The Main Characteristics}

\section{Functions}

A particular public service which only benefits a certain geographical area should be financed by the people living in this area, i.e. there should be no spill-overs. Under this rule, the different political units can cater for differences in the populations' preferences or, more precisely, to its demands. To minimize cost, these units have to exploit economies of scale in production. As these may strongly differ between functions (e.g., between schools, police, hospitals, power plants and defense) there is an additional reason for single-functional (or few-functional) governmental units of different sizes. While this idea is central to 'fiscal equivalence' as proposed by Olson (1969) and Oates (1972), the endogeneity of the size of governmental units constitutes an essential part of FOCJ. Moreover, fiscal equivalence theory has been little concerned with decision-making within functional units. The supply process is either left unspecified or it is assumed that the mobility of persons (and of firms, a fact rarely mentioned) automatically induces these units to cater for individual preferences. This criticism also applies to a closely related concept of fiscal federalism, namely 'voting by foot' (Tiebout 1956). This preference revealing mechanism makes comparatively efficient suppliers grow in size, and the others shrink. According to this model of federalism, the political jurisdictions are exogenously given, are multi-purpose, and do not overlap, while the political supply process is left unspecified. In contrast, we emphasize the need to explicitly study the political supply process. In line with Epple and Zelenitz (1981), exit and entry is considered insufficient to eliminate rent extraction by governments. Individuals must have the possibility to raise voice in the form of voting. Buchanan's 'clubs' (see Buchanan 1965, Sandler and

\footnotetext{
${ }^{13}$ A full account of the concept of FOCJ is provided by Frey and Eichenberger (1999). As always, there are precursors to FOCJ. The general idea has already been advanced by Montesquieu. In the economics literature a related concept has been pioneered by Tullock (1994), who somewhat misleadingly speaks of 'sociological federalism'. Casella and Frey (1992) discuss the concept and refer to relevant literature.
} 
Tschirhart 1980) are similar to FOCJ because their size is determined endogenously by club members' benefits and costs.

Overlap

FOCJ may overlap in two respects: (i) two or more FOCJ catering for the same function may geographically intersect (e.g., a multitude of school FOCJ may exist in the same geographical area); (ii) FOCJ catering to different functions may overlap. The two types of overlap may coexist; however, a constitutional decision can be taken to restrict FOCJ of specific functions to the second type because this alleviates free-riding problems (see below). An individual or a political community normally belongs to various FOCJ at the same time. FOCJ need not be physically contiguous, and they need not have a monopoly over a certain area of land. In this respect the concept of FOCJ is similar to Buchanan-type clubs which may intersect, but it differs completely from archaic nationalism with its fighting over pieces of land. It also breaks with the notion of federalist theory that units at the same level may not overlap.

\section{Competition}

In FOCJ, two mechanism guarantee that empowered politicians conform closely to their members' preferences: while the possibility for individuals and communities to exit mimics market competition (Hirschman 1970), their right to vote establishes political competition (see Mueller 1989). It should be noted that migration is only one means of exit; often, membership in a particular FOCUS can be often discontinued without changing one's location. Exit is not restricted to individuals or firms; as said before, political communities as a whole, or parts of them may also exercise this option. Moreover, exit may be total or only partial. In the latter case, an individual or community only participates in a restricted set of FOCUS activities. This enlarged set of exit options makes 'voting by foot' a real constraint for politicians.

'Secession', i.e. exit of jurisdictions such as states or regions, has been recognized in the literature as an effective mechanism for restricting the power of central states (e.g., Zarkovic Bookman 1992, Drèze 1993). Secession has been suggested as an important ingredient for a future European constitution (Buchanan 1991, European Constitutional Group 1993). The right to secede stands in stark contrast to the prevailing concepts of nation states and federations where this is strictly forbidden and often prevented by force, as is illustrated, e.g., by the American Civil War 1861-1865, by the Swiss 'Sonderbundskrieg' 1847, or more recently by the wars in Katanga (1960-63), Biafra (1967-70), Bangladesh (1970-71), and in this decade in Ex-Yugoslavia. Current European treaties do not provide for the secession of a 
nation from the European Union, and a fortiori for part of a nation or even for communities. A future European constitution thus plays a crucial role in shaping the possibility for lowerlevel jurisdictions to exit at low cost from particular sub-units (nations, states, Länder, autonomous regions, etc.) or even from the European Union as a whole.

For FOCJ to establish competition between governments, exit should be as unrestrained as possible. In contrast, entry need not necessarily be free. As for individuals in Buchanan-type clubs, jurisdictions may be asked a price if they want to join a particular FOCUS and benefit from its public goods. The existing members of the particular FOCUS have to democratically decide whether a new member pays an adequate entry price and thus is welcome. 'Free' mobility in the sense of a disregard for the cost imposed on others is overcome by internalizing the external cost of movement. In addition, FOCJ do not have to restrict entry by administrative and legal means such as zoning laws. Explicit, openly declared entry fees substitute implicit restrictions resulting in high land prices and housing rents. The commonly raised concern that pricing could be exploitative and mobility strongly curtailed is unwarranted as FOCJ are subject to competitive pressure. Moreover, the possibility to impose an explicit entry fee gives incentives to FOCJ-governments to care not only for the preferences of actual, but also of prospective members.

However, the exit option does not suffice to induce governments to act efficiently. Thus, competition needs to be enhanced by political institutions. The citizens should directly elect the persons managing the FOCJ, and should be given the right to initiate popular referenda on specific issues. These democratic institutions are known to raise efficiency in the sense of caring well for individual preferences (for elections, see Downs 1957, Mueller 1989; for referenda, see section 4).

\section{Jurisdiction}

A FOCUS is a democratic governmental unit with authority over its citizens, including the power to tax. According to the two types of overlap, two forms of membership can be distinguished: (i) The lowest political unit (normally the community) is a member, and all corresponding citizens automatically become citizens of the FOCJ to which their community belongs. In that case, an individual can only exit via mobility. (ii) Individuals may freely choose whether they want to belong to a particular FOCUS, but while they are its citizen, they are subject to its authority. Such FOCJ may be non-voluntary in the sense that one must belong to a FOCUS providing for a certain function, e.g., to a school-FOCUS, and must pay 
the corresponding taxes (an analogy here is health insurance which in many countries is obligatory but where individuals are allowed to choose an insurance company). The citizens of such a school-FOCUS may then decide that everyone must pay taxes in order to finance a particular school, irrespective of whether one has children. With respect to FOCJ providing functions with significant redistributive effects, a minimal regulation by the central government may be in order so that, e.g., citizens without children do not join 'school-FOCJ' which in effect do not offer any schooling but have correspondingly low (or zero) taxes. In this respect, Buchanan-type clubs differ from FOCJ, because they are always voluntary while membership in a FOCUS can be obligatory.

FOCJ as jurisdictions provide particular services but do not necessarily produce them themselves if contracting-out to a public or private enterprise is advantageous. It is noteworthy that present-day outsourcing by communities does not automatically lead to FOCJ. The former is restricted to production, while FOCJ care for provision and are directly democratically controlled. FOCJ also differ from existing functional and overlapping institutions such as the various kinds of specific administration unions (or Zweckverbände as they are aptly called in German speaking countries). These institutions normally do not have the legal status of governments but are purely administrative units. The same applies to the many types of corporations which usually have no power to tax but have to rely on charges.

\section{Beneficial Effects of FOCJ}

Due to its four essential characteristics, FOCJ compare favorably to traditional forms of federalism. One aspect concerns the governments' incentives and possibilities to satisfy heterogeneous preferences of individuals. As a consequence of the concentration on one functional area, the citizens of a particular FOCUS have better information on its activity, and are in a better position to compare its performance to other governments. As many benefits and costs extend over a quite limited geographic area, we envisage FOCJ to be often small which is also helpful for voters' evaluations. The exit option opened by the existence of overlapping jurisdictions is not only an important means to make one's preferences known to governmental suppliers but it also strengthens the citizens' incentives to be informed about politics (see Eichenberger and Serna 1996).

On the other hand, FOCJ are able to provide public services at low cost because they are formed in order to minimize interjurisdictional spill-overs and to exploit economies of scale. When the benefits of a specific activity indivisibly extend over large areas, and there are 
decreasing cost, the corresponding optimal FOCUS may cover many communities, several nations, or even Europe as a whole. An example may be defense against outward aggression where the appropriate FOCUS may most likely extend over the whole of Europe (even beyond the European Union). That such adjustment to efficient size is indeed undertaken in reality is shown by the Swiss experience. Communities decided by referendum whether they wanted to join the new canton Jura established in 1978, and in 1993 communities in the Laufental opted to belong to the canton Basel-Land instead of Berne. Communities also frequently change districts (the federal level below cantons) by referendum vote, which suggest that voters perceive the new size of jurisdictions and the new bundle of services to be more efficient. The same holds for American special districts.

The specialization on one or a few functions further contributes to cost efficiency due to the advantages of specialization. As FOCJ levy their own taxes to finance their activity, it pays to be economical. In contrast, in APJ (All-Purpose Jurisdictions) financed from outside lacking such fiscal equivalence, politicians have an incentive to lobby for ever increasing funds, thereby pushing up government expenditures. The incentive to economize in a FOCUS induces its managers to contract-out whenever production cost can thereby be reduced. While FOCJ are more market oriented than APJ, they reduce the size of the public sector. However, they differ from today's one-shot privatization, which usually does not impact on the governments basic incentives and thus is often reversed by re-regulation and de-privatization. In contrast, in a system of FOCJ privatization emerges endogenously and is sustainable, as the politicians incentives are changed fundamentally.

The threat of dissatisfied citizens or communities to exit the FOCUS, and the benefit of new citizens and communities joining, gives an incentive to take individual preferences into account and to provide the public services efficiently. Quite another advantage of FOCJ is that they open up the politicians' cartel ('classe politique') to functionally competent outsiders. While all-purpose jurisdictions attract persons with broad and non-specialized knowledge to become politicians, in FOCJ rather persons with a well-grounded knowledge in a particular functional area (say education or refuse collection) are successful. As the time burden of politicians in functional units is small compared to politicians in APJ, more citizens can take over political mandates.

Citizens participation possibilities are strengthened in FOCJ. Officials of FOCJ are elected rather than appointed in delegation hierarchies that lack democratic control. In addition, citizens of a FOCUS have the possibility to launch initiatives and referendums giving rise to 
direct citizen legislation. The participation aspect contributing to citizens perceived political effectiveness is further gaining by the possibility of non-professional political appointments. The possibility to form FOCJ helps to deal with issues raised by fundamentalist sentiments. Political movements focused on a single issue (e.g., ethnicity, religion, environment, etc.) are not forced to take over governments in toto but can concentrate on those functions they are really interested in. An ethnic group need not disassociate itself from the state they live in as a whole but may found FOCJ which care for their particular preferences. South Tyroleans, for example, unhappy with the language domination imposed by the Italian state, need not leave Italy in order to have their demands for cultural autonomy fulfilled, but may establish corresponding FOCJ. Such partial exit (e.g., only with respect to ethnic issues) does not lead to trade barriers often going with the establishment of newly formed all purpose political jurisdictions. FOCJ thus meet the criterion of market preserving federalism (see Qian and Weingast 1997).

A federal web composed of FOCJ certainly affects the role of the nation states. They will certainly lose functions they presently do not fulfil according to the population's preferences, or which they produce at higher cost than FOCJ designed to exploit cost advantages. On the other hand, the scheme does not purport to do away with nations but allows for multi-national as well as small scale alternatives where they are desired by the citizens. Nation states subsist in so far as they provide functions efficiently according to the voters' preferences.

\subsection{FOCJ in the Future and in the Past}

\section{Future Opportunities}

A careful consideration reveals, that there is a wide range of functional issues to which FOCJ could profitably be applied. A practical example is the policing of the Lake of Constance (which borders on two German Länder, two Swiss Cantons, and one Austrian Land) which involves the regulation of traffic, environmental protection, the suppression of criminal activities and the prevention of accidents. Formally, the various local police departments are not allowed to directly collaborate with each other, not even to exchange information. Rather, they must advise the police ministries of the Länder and cantons, which then have to notify the respective central governments which then interact with each other. Obviously, such a formal procedure is in most cases vastly inefficient and unnecessarily time consuming. In actual fact, the problems are dealt with by direct contact among the local police 
commissioners and officers. However, this is outside the law and depends to a substantial extent on purely personal relationships (which may be good or bad). A FOCUS committed to policing the lake would allow a pragmatic, problem oriented approach within the law - and would, moreover, be in the best 'spirit' of Europe.

FOCJ are not restricted to such small-scale functional issues but are relevant for all levels of government and major issues. An example would be Alsace which, while remaining a part of France in other respects, might partially exit by joining, say, the German social security or school system (with German as the main language), or might join a university-FOCUS involving the Swiss university of Basle and the German universities of Freiburg and Karlsruhe. Actually, the first steps for establishing such a university-FOCUS are under way. But these efforts contrast with the idea of regions as set out in the Maastricht Treaty (and elsewhere), not least because one of the participants (the university of Basle) is not part of the European Union. Another example refers to Corsica which according to Drèze's (1993) suggestion should form an independent region of Europe because of its dissatisfaction with France. However, most likely the Corsicans are only partially dissatisfied with France. This suggests that one or several FOCJ provide a better solution in this case; they may, e.g., especially focus on ethnic or language boundaries, or on Corsica's economic problems as an island. This allows the Corsicians to exit France only partially instead of totally. Quite generally, tourism and transport issues, in particular railroads, are important areas for FOCJ. It should be noted that, despite the membership of various countries in the (then) European Community, railroad policy was not coordinated to exploit possible economies of scale; a FOCUS may constitute a well-suited organization to overcome such shortcomings.

\section{Contemporary and Historical Forerunners}

The European Community started out as a FOCUS designed to establish free trade in Europe, and was from the very beginning in competition with other trade areas, in particular North America, Japan, and EFTA. Due to its economic success, it has attracted almost all European countries. But entry has not been free but the nations determined to enter had to pay a price. They have (with partial exceptions) to accept the 'acquis communautaire' as well as to pay their share to the Communities' outlays which to a large extent serve redistributive purposes. In several respects there exist FOCJ-like units within Europe such as with respect to police, education, environment, transport, culture or sports though they have been prevented to become autonomous jurisdictions with taxing power. 
Most of these functional units are not contiguous with the area of the European Union. Some are smaller (e.g., those organized along ethnic or language functions), and some are larger. Several East European countries and Switzerland which are not EU-members are certainly fully involved in, e.g., European culture, education or crime. FOCJ of the nature understood in this paper may therefore build upon already existing structures, and are in the best of European traditions.

There are two countries in which functional, overlapping and competing jurisdictions exist (though they do not in all cases meet the full requirements of FOCJ specified above).

\section{United States}

Single-purpose governments in the form of 'special districts' play a significant role in the American federalist system (ACIR 1982, 1987, Foster 1996, Nuun and Schoedel 1997). Their number has strongly increased, between 1967 and 1972 by 30.4 per cent, between 1972 and 1984 by 19.7 per cent, in both cases more quickly than other types of jurisdictions (Zax 1988). There are both autonomous and democratically organized as well as dependent special districts (e.g., for fire prevention, recreation and parks). Empirical research suggests that the former type is significantly more efficient (Mehay 1984). Our theoretical hypothesis of the opposition of existing jurisdictions against the formation of special districts is well borne out. In order not to threaten the monopoly power of existing municipalities statutes in 18 states prohibit new municipalities within a specified distance from existing municipalities (ACIR 1982, Zax 1988: 81); in various states there is a minimum population size required and various other administrative restrictions have been introduced (see, e.g., Nelson 1990). Empirical studies reveal that these barriers imposed by Local Agency Formation Commissions (LAFCO) tend to reduce the relative efficiency of the local administration (Di Lorenzo 1981, Deno and Mehay 1985), and tend to push upwards the local government expenditures in those municipalities which have introduced LAFCOs (Martin and Wagner 1978).

\section{Switzerland}

Many Swiss cantons have a structure of overlapping and competing functional jurisdictions which share many features of FOCJ. In the canton Zurich (with a population of 1.2 Mio), e.g., there are 171 geographical communities which in themselves are composed of three to six independently managed, direct-democratically organized communities devoted to specific functions and levying their own taxes on personal income: besides general purpose 
communities, there are communities that exclusively provide for elementary schools and other ones specializing in junior high schools, and there are the communities of three different churches. All these governmental units have widely differing rates of income taxes. Moreover, there is a vast number of 'civil communities' (Zivilgemeinden) providing water, electricity, TV antennas etc. which are direct-democratic but finance themselves by user charges. These communities often overlap with neighboring political communities. In addition there are 174 functional units (Zweckverbände as they are aptly called in German speaking countries) whose members are not individual citizens but communities. These Zweckverbände care, e.g., for waste water and purification plants, cemeteries, hospitals and regional planning. The canton Zurich is no exception in Switzerland concerning the multitude of types of functional communities. A similar structure exists, e.g., in the canton Glarus or Thurgau (for the latter, see Casella and Frey 1992). Various efforts have been made to suppress this diversity of functional communities, usually initiated by the cantonal bureaucracy and politicians. However, most of these attempts were thwarted because the population is mostly satisfied with the public supply provided. The example of Switzerland which is generally considered to be a well-organized and administered country - shows that a multiplicity of functional jurisdictions under democratic control is not a theorist's wishful thinking but has worked well in reality.

\section{Historical forerunners}

Decentralized, overlapping political units have also been an important feature of European history. The competition between governments in the Holy Roman Empire of German Nations, especially in today's Italy and Germany, has been intensive. Many of these governments were of small size. Not few scholars attribute the rise of Europe to this diversity and competition of governmental units which fostered technical, economic and artistic innovation (see, e.g., Hayek 1960, Jones 1981, Weede 1993 and Baumol and Baumol 1994 who also give a lively account of how the musical genius of Wolfgang Amadeus Mozart benefited from this system of government). While the Chinese were more advanced in very many respects, their superiority ended with the establishment of a centralized Chinese Empire (Pak 1995, Rosenberg and Birdzell 1986). The unification of Italy and Germany in the 19th century, which has often been praised as a major advance, partially ended this stimulating 
competition between governments and lead to deadly struggles between nation states. ${ }^{14}$ Some smaller states escaped unification; Liechtenstein, Luxembourg, Monaco, San Marino and Switzerland stayed politically independent, and at the same time grew rich.

The above mentioned governmental units were not FOCJ in the sense outlined in this contribution but they shared the characteristic of competing for labor and capital (including artistic capital) among each other. However, history also reveals examples of jurisdictions close to FOCJ. The problems connected with Poland's strong ethnic and religious diversity (Catholics, Protestants and Jews) were at least partly overcome by jurisdictions organized along these features, and not along geography (see, e.g., Rhode 1960, Haumann 1991). The highly successful Hanse prospered from the 12th to the 16th century, and comprised among others Lübeck, Bremen, Köln (today German), Stettin and Danzig (today Polish), Kaliningrad (today Russian), Riga, Reval and Dorpat (today parts of the Baltic republics) and Groningen and Deventer (today Dutch); furthermore, London (England), Bruges and Antwerp (today Belgian) and Novgorod (today Russian) were Handelskontore or associated members. It clearly was a functional governmental unit providing for trade rules and facilities and was not geographically contiguous.

\section{Direct Democratic Participation Rights}

In addition to a fiscally decentralized government, direct democracy is a second design element for local governance granting strong local power to citizens. There are many different meanings, conceptions and also misunderstandings about what "direct democracy" is. The following two aspects of the way the term "direct democracy" is used here are crucial ${ }^{15}$ :

\section{Referendums and Initiatives as Additional Rights}

Direct democracy (or, more precisely, semi-direct democracy) shifts the final rights in determining issues to the citizens. However, it does not substitute for parliament, government, courts and all the other features known in representative democracies. The extent of direct participation rights may vary, but they always include constitutional changes, normally by an

\footnotetext{
${ }^{14}$ According to Sperber (1994, p. 24), in the first half of the 19th century average income was higher in strongly decentralized Germany than in strongly centralized France, which may at least partly be attributed to the difference in the degree of centralization.

${ }^{15}$ See e.g. Magleby (1984), Cronin (1989), Butler and Ranney (1994), Frey (1994), Dubois and Feeney (1998), Kirchgaessner, Feld and Savioz (1999), Frey, Kucher and Stutzer (2001).
} 
obligatory referendum. Optional referendums and initiatives (allowing citizens to put issues on the political agenda) require a predetermined number of signatures by the citizens before they can take place.

From a historical perspective, three main stages of democracy may be distinguished:

- Classical democracy, first developed in Athens and other Greek city states. Participation rights were restricted to male citizens, thereby excluding a large number of the population, and extended only over a small area of a town. Yet the principles of democracy still revered and used today were developed there.

- The French Revolution extended democracy over a large area. The principle of representation made it possible to introduce indirect political participation to the nation state.

- Direct democracy combines these two earlier types of democracy by giving every citizen the right to decide on certain issues. The extreme (classical) form of having citizens decide on each and every issue is practiced nowhere today, but the number of issues on which citizens may vote varies widely between countries.

Over the period 1990 to 2000 , no less than 405 popular referendums on the national level were recorded (see Gross and Kaufmann 2002, Butler and Ranney 1994). More than half took place in Europe, namely 248 (and again half of them in Switzerland); 78 in America, 37 in Africa, 26 in Asia and 16 in Oceania. ${ }^{16}$ In the decade before (1980 to 1990), there were only 129 national referendums. Up until August 2002, issues of European integration led to no less than 30 national referendums. ${ }^{17}$ There is a very large number of popular referendums at lower levels of government. In the German state of Bavaria there were as many as 500 since its

\footnotetext{
${ }^{16}$ Some of these referendums certainly do not meet the requirement of leaving the (final) decision on an issue to the general electorate, but are rather plebiscites, i.e. votes where the government wants the support of the population for a decision already taken.

${ }^{17}$ An up-to-date account of the referendum experience around the world is provided by C2D Research and Documentation Centre on Direct Democracy at the University of Geneva (http://c2d.unige.ch/, September 20, 2004). Additional information about direct legislation in the United States is collected by the Initiative and Referendum Institute in Washington (http://www.iandrinstitute.org/, September 20, 2004). Its partner organization in Europe (http://www.iri-europe.org/, September 20, 2004) provides information on the state of direct democracy in European countries (with a special focus on transition economies).
} 
adoption. In Switzerland, there are thousands of referendums at all three levels of government: local, cantonal and federal.

Most democracies do not allow the general electorate to participate in taking important decisions. Nowhere (except in Switzerland and Liechtenstein) are popular referendums used in a regular and systematic way at the national level. In the United States, despite its many local popular decisions, and its frequent use in some States, such as California and Oregon, there is no referendum at the national level. Many important decisions shaping a country's fate for decades to come are not subject to a popular referendum. A telling example is Germany. The citizens had no say either with respect to the conditions for the integration of the former GDR or the dumping of the Deutsche Mark and introducing the Euro. Directly democratic decisions are, in many cases, not taken seriously by the politicians in power. A revealing example is the Irish vote on the Nice Treaty of the European Union. The citizens rejected it in June 2001. Before the second vote on the issue, due to take place in August 2002, EU politicians made it clear that they would go ahead with the Treaty's program, irrespective of whether the Irish vote would be positive or negative (though unanimity within the $\mathrm{EU}$ is required).

\section{Referendums and Other Forms of Consultation of Citizens}

Referendums are a right given to the citizens by the constitution. Government and parliament are bound by these rights: they are not free to ask the opinion of the citizens just when it suits them. This distinguishes referendums from plebiscites undertaken by governments to ex post sanction a decision already taken by them. With plebiscites, the citizens are not asked to decide on an issue, but only to express their support of the government. Referendums also fundamentally differ from opinion surveys, which are on the spot views of people, without any consequences for the government: they can choose to act in accordance with the results or disregard them. In contrast, when citizens have taken a decision in a referendum, the constitution obliges the government to put the corresponding policy into practice.

\subsection{Direct Democracy Against Politicians' Cartel}

\section{Politicians Against the Voters}

Persons acting within the confines of the political system have incentives to exploit it to their advantage. Politicians are not 'bad', or any worse than other persons, but they tend to be - as 
everyone else - self-regarding. They endeavor to further their own interests, which consist not only of material wealth, but also of recognition and prestige.

In a democracy, politicians can use three main ways of gaining benefits at the citizens' expense, or 'exploiting' the general population:

(a) Politicians may take decisions which they know to deviate from the voters' preferences. Political actors may do so because they have an ideology of their own, because they reap material and non-material advantages by so doing, or because they have insufficient information. For instance, politicians systematically prefer direct interventions in the economy to employing the price system, because regulations generally allow them to derive larger rents.

(b) Politicians secure themselves excessive privileges in the form of direct income for themselves or their parties, pensions and fringe benefits, such as cars and houses.

(c) Citizens' exploitation may take the form of corruption, i.e. direct payments for special services provided to payers, but not to others.

Politicians have a common interest to protect and extend these rents where possible. That means they have an incentive to form a cartel against the ordinary citizens. There is, however, a public good problem involved: an individual politician has an incentive to break out, if such action is positively sanctioned by the electorate. Such action can regularly be observed in democracies, but it is rarely of much consequence for the cartel. The politicians in many countries form a close-knit group of people clearly differentiated from the rest of the population. Their main contacts are within the group, so that the social disapproval of the few who dare to break out of the cartel is acutely felt and carries a high cost. Moreover, the cartel is administered by the leaders of the parties so that, in most countries and time periods, only a small number are involved, and the break-out of a politician is quickly and effectively sanctioned by the other members of the cartel, for instance by restricting access to parliamentary positions (in particular membership of powerful commissions), or by reducing the monetary support provided by the state to the parties. An individual politician finds it equally hard not to be a part of the cartel, because the leaders of his party have many means at their disposal to control him or her, including enforced resignation. 


\section{Constitutional Provisions Against the Politicians' Cartel}

All the actors involved, in particular the voters, are well aware that there are strong and ubiquitous incentives for the politicians to form a cartel and to exploit the voters. In response, one finds three quite different forms of institutions in democratic constitutions designed to check such action:

(a) Rules prohibiting the (excessive) appropriation of rents by the politicians, the most stringent ones being to prevent corruption. Obviously, such rules are only effective if they cannot easily be circumvented and if they are well enforced. Such provisions are completely useless against the first type of exploitation mentioned, namely the systematic deviation from citizens' preferences. As the privileges accorded by the politicians to themselves are of an extremely varied kind and are difficult to detect (especially with respect to pensions), experience shows that politicians' rent seeking can thereby scarcely be prevented. With respect to corruption, only the most blatant cases are found out. It must be concluded that, while such rules are of some use, they certainly are not able to prevent the exploitation of citizens to any significant extent.

(b) The establishment of special courts, with the task of preventing citizens' exploitation. All democratic countries know some institution of courts of accounts, but it may well be shown that they fulfill their role only to a limited extent. They are obviously the less effective, the more directly they depend on the politicians they are supposed to control. In this respect, it does not help much if the members of the court of accounts are elected and must answer to the parliament (instead of to the government), because the cartel includes politicians inside and outside the government. Even courts of accounts, formally independent of government and parliament, have little incentive and possibility of checking the exploitation of the citizens by the politicians. This applies particularly to the deviation from citizens' preferences; it may indeed be shown that courts of accounts, which necessarily have to focus on the formal correctness of politicians' and administrators' behavior, in some respects tend to widen the gap between what politicians provide and what the people want.

(c) Competition between parties is the classical institution in representative democracies to prevent politicians from pursuing their own goals at the population's expense. Constitutions are familiar with various devices to further competition and make a coalition between the politicians more difficult. One is the division of power between the 
executive, legislative and jurisdictional branches. Another is the establishment of two houses of parliament. Because of the many types of interactions existing, and the welldefined gains to be expected, these devices are rather ineffective in checking the interests of the 'classe politique'.

An important constitutional device for stimulating the competition between parties is to guarantee, and to facilitate, the entry of new politicians and parties into the political system. While this certainly forces the established parties in a democracy to take better care of the people's wishes and to be more careful with regard to privileges and corruption, the effects tend to be short-lived. The previous outsiders quickly realize that many advantages are to be gained by tolerating the politicians' cartel, and even more by participating in it. The experience of many countries supports this theoretical proposition. An example are the 'Green' parties, who at first fought against the political establishment, but within a surprisingly short time learned to take advantage of the taxpayers' money for their own purposes.

On the basis of these arguments, it must be concluded that neither constitutional rules, nor courts, nor party competition are particularly successful in reducing the possible exploitation of the general population by the politicians. It is not argued, of course, that the constitutional features elaborated are useless, but that they do not provide a sufficient safeguard against politicians' rent-seeking. It is therefore desirable to search for, and to seriously consider, other constitutional means of fighting the politicians' cartel.

\section{Referendums as a Constitutional Provision Against the Politicians' Cartel}

A referendum, in which all the citizens have the possibility of participating, meets the crucial requirement that it gives decision-making power to people outside the politicians' cartel. The individuals making the decision are not integrated into the 'classe politique' and they avoid the control of politicians. In an initiative, the demands are explicitly directed against the political establishment represented in parliament and government. Optional and obligatory referendums serve more of a controlling function because, if successful, they overrule the decisions taken by the executive and the legislative bodies.

A popular referendum (in the widest sense of the word) can only serve its purpose if the 'classe politique' cannot block it. In many countries, the Supreme Court or, even worse, the parliament, has the power to decide whether a referendum is admissible. The criteria appear to be purely formal but, in fact, the members of the 'classe politique' have a considerable 
number of possibilities and incentives to forbid referendums threatening the position of the politicians' cartel. Often vague concepts, based on what they consider to be the 'raison d'état', are employed. In other countries, such as Switzerland, almost no such possibility exists, and therefore issues may be brought to the vote which are not desired, and are sometimes even strongly disliked, by the politicians.

Empirical evidence shows that referendums are indeed able to break the cartel among the politicians by getting through constitutional provisions and laws totally against the interests of the 'classe politique'. The following cases refer to Switzerland, the referendums' nation par excellence. The first two cases concern important historical episodes (Blankart 1992).

(a) During the 19th century, the house of representatives (Nationalrat) was elected according to the majority rule. The largest party greatly benefited from that; throughout seven decades, the Radical-Democratic Party secured a majority of the seats. When the idea was raised that the elections should follow proportional representation in order to allow small parties to enter parliament, the then 'classe politique' amongst the executives and jurisdiction strongly rejected this proposal for obvious reasons of self-interest. Nevertheless, in 1918, the corresponding referendum was accepted by the majority of the population and the cantons. In the subsequent elections, the Radical-Democratic Party lost no less than 40 percent of their seats.

(b) Up until the Second World War, Urgent Federal Laws (dringliche Bundesbeschluesse) were not subject to (optional) referendums. In order not to have to seek the people's approval, and in order to pursue policies in their own interests, the 'classe politique' in the government and parliament often declared federal laws to be 'urgent', even if that was not in fact the case. In 1946, an initiative was started with the objective of preventing this disregard for the interests of the population. Again, the executive and legislative bodies urged the voters to reject the initiative, which was clearly one of self-interest. However, the initiative was accepted by the voters, and the politicians are now forced to take the citizens' interests into account when they decide on federal laws.

The history of Swiss voting provides many more examples of such clashes between the opinions of the leaders and the citizens. The politicians have to make great efforts to endorse as quickly as possible any movements originating from outside the cartel. Sometimes it is established parties (but usually at the fringes of the cartel), or associated interest groups, which initiate referendums. If this strategy is to be successful, the politicians have to at least 
partially take into account the population's preferences, and have to reduce the extent of their rent seeking. The institution of the referendum in this case leads indirectly to the desired outcome that the politicians' cartel has less leeway ${ }^{18}$.

Politicians are well aware that the institution of popular referendum severely restricts their possibility of "exploiting" the citizens/taxpayers and they therefore oppose introducing elements of direct democracy.

\subsection{Referendums as a Process}

It would be mistaken to consider a referendum just to be a vote. Indeed, two important stages before and after the vote need to be considered.

\section{The Pre-Referendum Process}

The constitutional setting determines to a large extent which issues are put on the political agenda, and which are prevented from appearing. In representative democracies, politicians are often very skilled at not letting problems, which are to their disadvantage, be discussed in the democratically legitimized institutions. As has been shown, both theoretically and empirically, agenda setting power has a significant effect on voting outcomes. ${ }^{19}$

An important feature of referendums is the discussion process stimulated among the citizens, and between politicians and citizens. ${ }^{20}$ Pre-referendum discussions may be interpreted as an exchange of arguments among equal persons taking place under well-defined rules. This institutionalized discussion meets various conditions of the "ideal discourse process", as envisaged by Habermas (1983). The relevance of discussion for politics induces citizens to participate, depending on how important the issue in question is considered to be. The experience of Switzerland shows indeed that some referendums motivate intense and farreaching discussions (such as the referendums on whether to join the European Economic

\footnotetext{
${ }^{18}$ Citizens' initiatives also allow an "unbundling" of issues, compared to the bundled issues typical for representative democracies. This induces policy outcomes that have a closer relationship with popular preferences (see Besley and Coate 2000).

${ }^{19}$ See Romer and Rosenthal $(1978,1982)$ for Oregon school budget referendums, and Weingast and Moran (1983) for congressional Committees. The two groups of researchers do not consider the general role of referendums in agenda setting, but concentrate on its effect on bureaucratic decisions. Our emphasis is on its role as a means to break the politicians' cartel.

${ }^{20}$ The essential role of discussion in direct democracy is more fully discussed in Frey and Kirchgaessner (1993), Bohnet and Frey (1994). For democracy in general, see Dryzek (1990).
} 
Space with a participation rate of almost 80 percent, compared to an average of roughly 40 percent). Other referendums considered to be of little importance by the voters engender little discussion and low participation rates (as low as 25 percent). This variability in the intensity of discussion and participation overrides the much studied "paradox of voting" (Tullock 1967, Riker and Ordeshook 1973).

The main function of the pre-referendum process is certainly to raise the level of information of the participants (for empirical evidence, see the next sub-section). It may, moreover, be hypothesized that the exchange of arguments also forms the participants' preferences. What matters most is that this preference formation can be influenced by, but not controlled by, the 'classe politique'.

A further important aspect of the referendum process is going beyond outcome considerations. Citizens may benefit from the process as such, as it is well established that people have a preference for participation in decision-making because it enhances individuals' perception of self-determination (for references on participation, see section 3.1). With regard to direct democracy, Cronin (1989), for example, notes, that "giving the citizen more of a role in governmental processes might lessen alienation and apathy" (p. 11). Moreover, the political discussion induced by initiatives and referendums generates a common understanding for different political opinions and positions. Individuals learn that their private interests are intimately linket do the interests of fellow citizens. This strengthens the social contract based on consensus and motivates people to go beyond acting out of narrow self-interest. Possibilities for direct democratic participation are thus considered an important source of perceived procedural fairness, affecting individual behavior.

\section{Post-Referendum Adjustments}

In a referendum, a political decision is formally made, but this does not necessarily mean that the politicians and the public administration take the appropriate action to implement it. The more legitimate the constitution is taken to be in a political system, the higher are the costs of not following it. The politicians may also be induced to act in such a way by the threat of not being reelected by the voters, but ultimately the extent of implementation depends on whether the constitutional rules are voluntarily obeyed by the persons in power.

The question of which side gets a majority in a referendum is not the only thing that matters. A referendum also clearly reveals how the population feels about the matter, and where and how large the minorities are. Groups dissenting from the majority are identified; their 
preferences become visible and become part of the political process (see Gerber 1997). This makes it more likely that particular parties start to champion their cause in order to win additional support, and for referendums to take place in particular regions.

Switzerland again provides a suitable example. In 1989, a popular initiative demanded that the Swiss Army be completely disbanded. Many Swiss considered this to be an attack on one of the almost "sacred" institutions of the country. The 'classe politique' was totally against the initiative, and the generals threatened that they would retire if the initiative was not overwhelmingly rejected (they spoke of a percentage of no-votes between 80 and 90 percent). The referendum outcome was a surprise to everybody, because one third of the voters (and a majority among the young voters eligible for military service) voted for the dissolution of the army. After a short period of shock, several parties suggested changes in the army which were implemented within a short time - changes which, before the referendum, were considered by everyone to be impossible to achieve.

\subsection{Empirical Evidence on the Consequences of Direct Democracy}

Direct democracy changes the political process in three important ways, compared to a purely representative democracy, as has been argued in the last section: (i) Due to a restriction of established politicians' power, an outcome of the political process can be expected that is closer to the citizens' preferences. (ii) The participatory character of direct democratic decision-making provides incentives to voters to inform themselves about political issues, and changes their relationship to authorities and fellow citizens. The referendum process might thus be a source of procedural utility. (iii) Direct democracy affects institutional change, and protects rules that favor the citizens; in particular, it is a safeguard against the risks of overcentralization.

In order to substantiate these hypotheses, systematic empirical analyses are necessary. A number of studies exist for both Switzerland and the United States (for surveys see, e.g., Bowler and Donovan 1998, Eichenberger 1999, Kirchgässner, Feld and Savioz 1999, Gerber and Hug 2001 or Matsusaka 2004). The two countries are particularly suited for comparative empirical analyses, because direct democratic rights are developed to a very different extent at the level of Swiss cantons and US States respectively. While we briefly mention a wide range of results, some particularly important findings are presented in greater detail. 


\section{Effects on Policy Outcomes}

In order to study whether direct democracy makes a difference to the outcomes of the political process, a natural starting point is to begin with public expenditures and revenues. Fiscal decisions are the central activities of most governments, and policy priorities are to a large extent formed in the budgeting process.

In a study covering the 26 Swiss cantons and the years between 1986 and 1997, Feld and Kirchgässner (2001) measure the effects of a mandatory fiscal referendum on aggregate expenditure and revenue. In 217 cases of the totally 312 annual observations, cantons adopt a mandatory referendum on new expenditure above a given threshold. It is found that expenditure and revenue in cantons with fiscal referendums are lower by about 7 percent and 11 percent respectively, compared to cantons that don't have this institutional provision. ${ }^{21}$ In a sample of 132 large Swiss towns in 1990, the same authors replicate their test for the mandatory referendum on budget deficits. In cities where a budget deficit has to be approved by the citizenry, expenditure and revenue, on average, are lower by about 20 percent, while public debt is reduced by about 30 percent. With an extended panel data set from 1980 to 1998, the effect of the mandatory expenditure referendum is analyzed, taking the spending threshold into account (Feld and Matsusaka 2003). At the median threshold of 2.5 million Swiss francs (SFR), spending per capita is reduced by 1,314 SFR, i.e. by 18 percent for an average expenditure level of 7,232 SFR (compared to cantons that either have an optional financial referendum or no referendum on new public expenditure). ${ }^{22}$ The difference in overall spending significantly varies between cantons, applying a low threshold of 0.5 million SFR $\left(25^{\text {th }}\right.$ percentile) and a high threshold of 15 million SFR $\left(75^{\text {th }}\right.$ percentile $)$. For the former, expenditure is estimated to be lower by $1,389 \mathrm{SFR}$, while for the latter the reduction is 845 SFR. Moreover, it is found that the mandatory financial referendum has less effect when it is easier for citizens to launch an initiative for a new law or to change an existing law (measured by the signature requirement). Thus, there is a substitutive relationship between the two institutions with regard to their consequences on cantonal fiscal outcomes.

\footnotetext{
21 While these findings imply larger deficits and higher public debt in cantons with a fiscal referendum, ceteris paribus, the respective empirical results neither show statistically significant effects on the former measure nor on the latter one (Feld and Kirchgässner 2001, p. 354).

${ }^{22}$ In the regression equation, the following are controlled for: income level in the canton, federal aid, age structure of the population, population size, population density, unemployment rate, as well as whether people are German-speaking or not.
} 
Very similar results are found for analyses across US States (Matsusaka 1995, 2004). In a panel from 1970 to 1999, including all states except Alaska, the effect of the initiative right is estimated on public expenditure, as well as on revenue. The institutional variable (a dummy variable) captures any type of initiative, whether it is statutory or for a constitutional amendment. After controlling for the average income in the state, federal aid, population size and growth, the percentage of metropolitan population and whether it is a southern or western state, initiative states, on average, have lower expenditure, as well as lower revenue, than noninitiative states. States with the initiative spend $\$ 137$ less per capita than states that do not provide the initiative, ceteris paribus. They also raise less revenue, $\$ 117$ per capita compared to non-initiative states. Both effects are about 4 percent, compared to average expenditure and revenue respectively. The effects are, however, significantly different when the signature requirements to launch an initiative are taken into consideration. States with a 2 percent requirement are estimated to levy \$ 342 less taxes and fees per capita than non-initiative states (for the modal signature requirement of 5 percent, revenue is 6 percent lower and expenditure is 5 percent lower) (Matsusaka 2004, chapter 3). These effects reflect robust results that can be assigned to the referendum process and not, for example, to the ideology of a state's electorate. Controlling for roll call voting of state senators, as a proxy for voters' conservatism, does not change the results in a substantive manner; if anything, the effects for the institutional variable increase (Matsusaka 2004, chapter 3).

Often these kinds of results are interpreted as clear evidence that direct democracy produces favorable outcomes for the citizens. However, they mainly provide clear evidence against a simple median voter world, in which representatives implement the preferred expenditure and revenue levels of the median voter, and referendums and initiatives would have no effect. ${ }^{23}$ It could well be that low expenditure and revenue levels mainly serve some well-organized interests (e.g. rich people) that rely less on public services. Therefore, the efficiency in the provision of public goods has to be analyzed.

\footnotetext{
${ }^{23}$ In contrast, Pommerehne (1978) provides strong evidence that the median voter model performs better in Swiss towns with extended direct democratic rights than in representative democratic cities. While, for the former category containing 48 of the 110 towns in the data set, a statistically significant demand elasticity for aggregate public expenditure with respect to income is estimated in 1970, this is not the case for representative democracies. Thus public expenditure seems to match median voter's preferences better in direct democratic jurisdictions.
} 
The cost efficient use of public money under different institutional settings can be directly studied for single publicly provided goods. In a careful study on waste collection, Pommerehne $(1983,1990)$ finds that this service is provided at the lowest cost in Swiss towns that have extended direct democratic participation rights and choose a private contractor. If the services are provided by the town instead of a private company, costs are about 10 percent higher. Efficiency losses are about 20 percent in purely representative democratic towns (compared to direct democratic ones). The average cost of waste collection is the highest in towns that rely on representative democratic decision-making only, as well as on publicly organized collection (about 30 percent higher than in the most efficient case).

A hint on the efficiency of public services comes from a study that relates fiscal referendums to economic performance in Swiss cantons (Feld and Savioz 1997). For the years 1984 until 1993, a neoclassical production function is estimated that includes the number of employees in all sectors, cantonal government expenditure for education including grants, as well as a proxy for capital based on investments for building and construction. The production function is then extended by a dummy variable that identifies cantons with extended direct democratic participation rights in financial issues at the local level. Total productivity - as measured by the cantonal GDP per capita - is estimated to be 5 percent higher in cantons with extended direct democracy, compared to cantons where these instruments are not available.

Based on an aggregate growth equation, Blomberg et al. (2004) analyze to what extent public capital (utilities, roads, education, etc.) is productively provided and whether there is a difference between initiative and non-initiative states in the United States. Data on gross state product, private and public capital, employment and population are for 48 US states between 1969 and 1986. They find that non-initiative states are only about 82 percent as effective as states with the initiative right in providing productive capital services, i.e. approximately 20 percent more government expenditure is wasted where citizens have no possibility to launch initiatives, compared to states where this institution is installed.

Interesting indirect evidence for the efficiency of referendums and initiatives offers a comparative study of land prices in 91 municipalities in Connecticut (Santerre 1986). Property prices are significantly higher in municipalities that provide direct democratic rights, compared to municipalities that do not.

In section 4.1, we outlined a politico-economic process in which politicians form a cartel against citizens. Previous results could, however, also be explained by imperfect information 
that lead benign representatives to implementing inferior policies, which happens less frequently in cantons, municipalities and states with direct democratic rights. While we do not reject the notion of well-intentioned representatives, differences in the level of efficiency are hypothesized to be due to differences in legislative shirking. Corresponding evidence is provided by a study on corruption in US states in 1998 (Alt and Lassen 2003). The misuse of public office for private gains is measured based on a survey of state house reporters' perception of public corruption. It is found that, in addition to a number of control variables, there is a statistically significant effect of voter initiatives on perceived corruption. In initiative states, corruption is lower than in non-initiative states, and this effect is the larger, the lower the signature requirement to launch an initiative. The result is further qualified, as there is only a negative effect on corruption for direct initiatives (but not for indirect initiatives, that have to be approved by the legislator).

Beyond the efficient provision of public goods and services, the consequences of direct political participation rights can be studied for citizens' happiness. Individuals not only have preferences for material affluence, but also with regard to freedom, equal opportunities, social justice or solidarity. Whether, overall, individuals' preferences are better served in direct democracies than in representative democracies can be conjectured, but not deduced, based on the extensive previous evidence. In contrast, the analysis of people's reported subjective wellbeing (for an introductory survey, see Frey and Stutzer 2002) can offer important evidence on whether people in direct democracies are happier.

In a study for Switzerland in the early 90s, the effect of direct democratic participation rights on people's reported satisfaction with life is empirically analyzed (Frey and Stutzer 2000). Survey answers are from more than 6,000 interviews. The proxy measure for individual utility is based on the following question: 'How satisfied are you with your life as a whole these days?' People answered on a scale from one (=completely dissatisfied) to ten (=completely satisfied). The institutionalized rights of individual political participation are measured at the cantonal level, where there is considerable variation. A broad index is used that measures the different barriers preventing citizens from entering the political process via initiatives and referenda across cantons. ${ }^{24}$ The main result is a sizeable positive correlation between the

\footnotetext{
${ }^{24}$ The index is based on the four main legal instruments for directly influencing the political process in Swiss cantons: (i) the initiative to change a canton's constitution, (ii) the initiative to change a canton's laws, (iii) the compulsory or optional referendum to prevent new law or the changing of law and (iv) the compulsory or optional referendum to prevent new state expenditure. Obstacles are
} 
extent of direct democratic rights and people's reported subjective well-being (after taking important socio-demographic and socio-economic variables into account). An increase in the index of direct democracy by one standard deviation raises the proportion of people indicating very high satisfaction with life by approximately 3.4 percentage points (or about 0.14 unit on the 10-point scale). This effect is more than a third as large as the difference in life satisfaction between the lowest income category and the one reporting the highest life satisfaction. As the improvement affects everybody, the institutional factor capturing direct democracy is important in an aggregate sense.

\section{Effects on the Process of Political Decision-Making}

Direct democracy fundamentally changes the process of political decision-making. It is not only that politicians are more restricted to follow citizens' preferences, but the direct involvement of the people changes their motivation when they act as voters, taxpayers or fellow citizens (Frey 1997). This can explain systematic differences as to how well aware of political issues people are, whether they can build up a relationship based on trust to public authorities, and whether they have a preference for, and gain procedural utility from, direct democratic participation rights as such.

It is widely believed that well-informed citizens are an essential prerequisite for a well functioning and stable democracy. If citizens do not have sufficient information about the policies or candidates they vote for, they may be disappointed by the actual consequences of their decisions, which in turn can undermine the acceptance and legitimacy of democracy as a political system. However, collecting information in order to make an informed decision at the poll is a public good that citizens are only willing to make to a limited extent. On the one hand, it can be debated whether a direct democratic decision on a particular issue demands more or less information than the choice of a candidate, given the institutions that lower citizens' information costs. ${ }^{25}$ On the other hand, it can be asked whether the level of voter

measured in terms of (i) the number of signatures necessary to launch an instrument (absolute and relative to the number of citizens with the right to vote), (ii) the legally allowed time span in which to collect the signatures and (iii) the level of new expenditure per head allowing a financial referendum. Each of these restrictions is evaluated on a six point scale: 'one' indicates a high obstacle, 'six' a low one (compulsory referenda are treated like referenda with the lowest possible obstacle). Average nonweighted ratings represent the measure used for direct democratic rights in Swiss cantons.

${ }^{25}$ Voters can use party ideologies to proxy for the consequences of their vote. They also pay attention to the previous performance of a government; they judge the reputation of candidates (Lupia and 
information itself is dependent on the political system in which citizens live. We have theoretically argued in the last sub-section that a political system which gives citizens more political participation possibilities will change the demand for political information, as well as the supply of it. An illustrative example is the introduction of the Maastricht Treaty in various European countries. In the countries where citizens had the right to vote on it (e.g. Denmark), politicians had to engage much more in explaining the Treaty to the citizens than in countries where no referendum took place (e.g. Germany). For the citizens the incentives to be informed were greater, as the intense discussions before the referendum partly transformed 'having a reasoned opinion' into a private good. Casual observation suggests that, as a consequence, information levels on the content of the Treaty were high among Danish citizens. While this example offers suggestive evidence that voters are better informed when they have a larger say in the political process, Benz and Stutzer (2004) provide more systematic evidence.

They study voter information in two different contexts. First, survey data from the Eurobarometer series is used to systematically investigate how referenda in several European countries affected citizens' information on the European Union (EU). The results indicate that people in countries with a referendum are in fact "objectively" better informed (according to 10 questions about the EU in the 1996 Eurobarometer), as well as feeling "subjectively" better informed about the EU after a referendum (Eurobarometer 1992 - 1997).

Second, they look at voter information in Switzerland. As a proxy measure for citizens' awareness of political issues, the number of correct answers to the following three questions is used: (i) "How many parties are in the Federal Council?" (ii) "Who was the president of the Federal Council in 1995?" And (iii) "How many signatures are required for an initiative?" Data is obtained from a large survey conducted among the Swiss electorate in 1996. Differences across cantons are explained by a measure for the extent of citizens' participation rights, as well as a number of socio-demographic control variables. In this study, the same broad index is used as in the work on direct democracy and life satisfaction in Switzerland (described above). A raw correlation is presented in figure 5.

[Figure 5 about here]

McCubbins 1998); they evaluate voting recommendations by interest groups (Schneider 1985, Lupia 1994); or they collect political information as a by-product of mass media consumption. 
It shows that, on average, citizens living in more direct democratic jurisdictions are objectively better informed about politics. The result holds in a multiple regression framework and indicates that the effect is sizeable. For the full range of the institutional variable, an effect is estimated that is comparable to an increase in education from mere compulsory education to having attended a college providing a diploma at the end.

The study by Benz and Stutzer (2004) also indicates that political participation possibilities raise discussion intensity which, in the literature, is seen as an important transmission channel that leads to higher voter information.

People's satisfaction with the provision of public services in direct democracies is likely to influence their behavior as voters collecting information or as taxpayers. However, the process of decision-making may also change people's trust in authorities (this can be seen as a psychological contract, Feld and Frey 2002) and their motivation to obey the law. It has, for example, been shown that, with more extensive democratic participation rights, people have higher tax morale and evade taxes less. Based on survey data from the World Values Study, Torgler (2003) finds that, in more direct democratic Swiss cantons, citizens are more likely to agree with the statement that "cheating on taxes if you have a chance" is never justifiable. Pommerehne and Weck-Hannemann (1996) directly study tax evasion in Swiss cantons and find that it is substantially lower where citizens have a direct impact on budgetary policy.

The evidence mentioned in this subsection leads to the hypothesis that citizens might benefit from the process of direct democracy, beyond its political outcomes. Stutzer and Frey (2004) extend the study mentioned above on direct democracy and life satisfaction to address this hypothesis. In order to disentangle outcome effects and procedural effects that make for the positive correlation between participation rights and reported subjective well-being, foreigners are used as a control group. Foreigners benefit from favorable outcomes, but are excluded from procedural benefits. In fact, it is found that the positive effect of direct democratic participation rights is about three times as large for citizens as it is for foreigners.

\subsection{Arguments against and Counter-Arguments for Referendums}

Systematic evidence has been accumulated that direct democracy is a process and provides outcomes that are more in line with citizens' preferences than are a purely representative democratic process and its outcomes. Nevertheless, referendums can hardly be considered a 
popular institution in democracies, not to speak of authoritarian systems. Not surprisingly, the members of the 'classe politique' are quick to raise many objections, because they realize that referendums constitute a threat to their position, by limiting their rent seeking potential. Many intellectuals - even those who do not share in the spoils of the politicians' cartel, and those opposing the political establishment - also reject referendums, with a variety of arguments. The basic reason is that they consider themselves to be better judges of what is good for the people than the citizens themselves. They tend to see themselves in the role of "philosopherking', determining what 'social welfare' is. Consequently, they prefer decision-making systems where they have a larger say. Thus, they oppose referendums for the same reasons as they oppose the market.

The following 10 arguments are often raised against the institution of the referendum. In addition to the empirical evidence in the last section, we respond to these claims with additional arguments.

\section{"Citizens Fail to Understand the Complex Issues"}

It is argued that the average voter is not well informed nor well educated, so that he or she cannot reasonably be allowed to determine political issues; this is the task of a specialized group, the politicians, who represent the voters.

This view can be refuted for various reasons:

First of all, it is inconsistent to trust citizens to be able to choose between parties and politicians in elections, but not between issues in referendums. If anything, the former choice is more difficult, as one must form expectations on how politicians will decide on future issues.

Secondly, the voters need not have any detailed knowledge about the issues at stake. Rather, they only need to grasp the main questions involved. These main questions are not of a technical nature, but involve decisions of principle, which a voter is as qualified to make as a politician.

Thirdly, the general intelligence and qualifications of politicians should not be overrated. They can hardly be considered to be consistently superior to other people. Moreover, the average Member of Parliament has little choice; he or she is normally forced to vote according to what the party superiors and a few specialists have decided in advance. 
Fourthly, a number of institutions have emerged in direct democracies, helping citizens to reach reasoned decisions. The parties and interest groups give their recommendations concerning decision-making, which the citizens may take into consideration. Even more importantly, the discourse in the pre-referendum stage brings out the main aspects and puts them in perspective.

Finally, as shown in the last section, citizens' information on political issues has to be taken endogenously. Direct democracy provides incentives for the citizens to privately collect information, and for the political actors and the media to provide it.

\section{“Citizens Have Little Interest in Participating”}

Participation in initiatives and referendums is often quite low. Sometimes only a few eligible voters go to the polls. It can be concluded from that that citizens are not interested in the issues to be decided on.

This is, however, a wrong conclusion for three reasons:

Firstly, the voting participation is not always so low. When the citizens feel that the issue is important, the voting participation rises considerably. Switzerland provides a good example of this variability: while average participation for all issues at the federal level is around 45 percent, it can be as low as 25 percent. But sometimes it goes up to 80 percent and more, as was the case in 1992, when the Swiss citizens had to decide whether they wanted to join the European Economic Area or not.

Secondly, high voting participation is not necessarily a good thing. Citizens are perfectly rational not to participate when they find the issues unimportant or when they are undecided. It could even be argued that it is socially beneficial that citizens do not participate under these conditions, but rather leave the decision to those for whom the issue really matters. Voting participation then reflects citizens' preference intensities, which makes the vote socially more valuable.

Thirdly, it would be naive to think that freely chosen voting participation in parliaments is very different from how citizens behave with respect to popular referendums. Today's Members of Parliament are highly specialized and seriously consider the pros and cons of only a few issues. In the case of all other issues, they (have to) follow the dictate of the party leadership, i.e. they do not cast a voluntary vote. This is reflected in the often extremely low 
participation in a parliamentary session. The Members of Parliament have to be herded together from the lobby or their offices to cast the dictated vote.

\section{“Citizens Are Easy to Manipulate”}

Financially strong parties and pressure groups are better able to start initiatives and to engage in referendum propaganda than are financially poor and non-organized interests. This cannot be denied. However, the perspective is wrong because it takes an absolute stance: it is always true that the rich and well-organized groups wield more power. The crucial question is whether they have more or less power in a direct than in a representative democracy. It is well known that well-organized and financed pressure groups exert considerable power over the politicians sitting in parliament and in government. It may even be argued that it is cheaper to influence the small number of legislators and government politicians than the total electorate.

\section{"Citizens Are Prone to Decide Emotionally"}

Voters are often supposed to be unduly influenced by emotional considerations. Again, this charge must be considered in a comparative perspective. There is little reason to believe that politicians are less subject to emotions. After all, parliaments are known to have highly emotional debates, sometimes even erupting into fist fighting. For that reason, many parliaments have formal procedures to debate a proposal two or even three times, with considerable time elapsing in between. The same holds for popular referendums. Before taking the vote, there must be time for intensive discussion, which allows the various sides of a question to be brought up. This strongly increases the chances of a decision dominated by rational aspects. ${ }^{26}$

\section{"There Are too Many Referendums Confusing the Voters"}

When the citizens have to simultaneously decide on a great many issues (in California, for instance, the voters often have to deal with 20 or even more propositions), they focus on a few clear issues. The decisions on all other issues are then haphazard and lack rationality.

\footnotetext{
${ }^{26}$ In July 2002, the German Bundestag debated (and rejected) a proposal to introduce elements of direct democracy at the federal level. For fear of emotional decisions, the introduction of the death penalty was excluded right from the very beginning as a subject for a referendum. This overlooks that an extensive discussion among the citizens, and with experts and politicians, brings to the fore all sides of the issue. A purely emotional decision is unlikely to occur. Moreover, many countries using the death penalty follow the representative principle (the United States being an example), while the country with most extensive direct democracy (Switzerland) prohibits the death sentence.
} 
This is indeed a situation to be avoided. However, the number of referendums put to the vote can be steered by the number of weekends with ballots over the year and by the number of signatures required for an initiative or optional referendum. If the number of issues to be decided on gets too large, the number of signatures required can be raised. Such a decision should be taken by a constitutional referendum to prevent the 'classe politique' from fixing such a high number of signatures that referendums become improbable.

\section{"Political Leadership Is Impossible"}

Politicians are sometimes supposed to make unpopular decisions. An example would be a restrictive fiscal policy, when the budget deficit is getting too high or when inflation soars. Such policy pays off only over the medium or even long term. It is argued that such unpopular policies would be impossible in a direct democracy.

This conclusion however does not necessarily hold. In a direct democracy, the politicians are forced to explain their policies to the citizens. If they can give good reasons why they propose to undertake such a seemingly unpopular policy, the citizens will not oppose it. There are many examples in Switzerland where the citizens are prepared to support policies burdening them, provided the politicians make an effort to explain why the sacrifice is necessary to improve the situation long term. Empirical evidence presented in the last section, for example, shows that fiscal stability is higher in Swiss cantons and US states with more extensive direct democratic participation rights.

\section{"Referendums Are Inadequate for Major Issues"}

As the voters are taken to be poorly educated and ill informed, subject to manipulation and to emotional decisions, it is often argued that referendums should only be used for small and unimportant issues. In contrast, issues of great consequence - such as changes in the constitution - should be left to the professional politicians.

The opposite makes more sense. Major issues can be reduced to the essential content. Evaluation is then not a matter of (scientific) expertise but of value judgments. Following methodological individualism, only the citizens may be the final judges when it comes to preferences, and a substitution by representatives is, at most, a second best solution. As the politicians have a systematic incentive to deviate from the voters' preferences, a substitution leads to biased outcomes. 


\section{"Referendums Hinder Progress"}

Asking the population to make a decision is often rejected because it is argued that the 'ordinary citizens' do not like changes, and that they prevent the adoption of 'bold, new ideas'.

It may well be true that many new propositions are rejected in referendums, but this does not mean that this constitutes a disadvantage. The fact that proposals contain new ideas is no proof of their quality. Indeed, the citizens are right in rejecting them when they are in favor of the 'classe politique'. The concept of 'bold, new' solutions is not rarely the result of technocratic thinking and of a planning mentality. They strengthen the politicians' and bureaucrats' position, but need not necessarily be in the voters' interests.

Referendums are a well-proven procedure to break deadlocks in societal decision-making and, in this sense, are progressive. There are cases in which an issue is difficult to resolve in parliament and government, and where a referendum helps to clear the issue. An example is the demands by regions for more independence. These demands are often accompanied by considerable violence and bloodshed. The Basque country is just one of many cases. In a direct democracy, such heated issues may be brought to a resolution acceptable to a large majority. In Switzerland, for instance, the secession of the Jura from the canton Bern was achieved by undertaking a number of referendums. While some minor violence took place, the issue was settled with much less strife and bloodshed than normally occurs in representative democracies, let alone autocratic systems.

\section{“Referendums Destroy Civil Rights"}

One of the fundamental problems of democracy is the "tyranny of the majority". This danger is seen to be particularly acute in the case of referendums, where the will of the majority is unrestricted. As a result, civil rights may be thwarted. But this is not necessarily the case. Most importantly, if there are economic, social and political cross cleavages, no group of citizens is always in the majority, and therefore will be careful not to antagonize other social groups. Empirically, some evidence for the suppression of civil rights has been found in local and state ballots in the United States (Gamble 1997), but there is also contrary evidence for the USA and Switzerland (Cronin 1989, Frey and Goette 1998). In a study on 51 California ballot propositions, the notion of cross cleavages is supported. Hajnal et al. (2002) find that black, Latino and Asian American voters are only about one percent less likely than white voters to be in the winning majority of the vote. 


\section{"Referendums Are Expensive”}

The last argument against referendums is the alleged high cost of undertaking them from an administrative point of view. It is argued that parliamentary decisions are much less expensive and should therefore be favored.

There are two reasons why this reasoning is fallacious:

Firstly, referendums are not expensive compared to the large cost of running a professional parliament with its accompanying party system (see e.g. von Arnim 1988 for Germany). As in a direct democracy, the final say is with the citizens, and less money needs to be spent on parliament and the parties. Moreover, the administrative costs of referendums are not high, because several propositions can be dealt with in one weekend, and citizens can be asked to actively participate in organizing the vote and counting the votes. While the citizens drafted suffer some opportunity cost, such a participation has the advantage of getting them more directly involved in governing their state, which tends to raise their sense for citizens' duties.

Secondly, the administrative cost of running referendums is immaterial compared to their major advantage, namely to significantly reduce the deviation of political decisions from individual preferences.

\section{Interaction between Federal and Democratic Institutions}

The institution of citizens directly deciding on an issue and the decentralization of decision making are closely connected. Federalism is an alternative means for better fulfillment of the voters' preferences: individuals tend to turn away from unsatisfactory jurisdictions, while they are attracted to those caring for the people's preferences at low cost. The possibility to vote with one's feet tends to undermine regional cartels by politicians.

The relation between direct democracy and federalism is not restricted to the common goal of a better fulfillment of citizens' preferences. Rather, the two institutions are mutually dependent. In particular, the citizens are interested in a working federal competition between jurisdictions. In order for the citizens to defend themselves against politicians' interests in the case of centralization, they need strong political rights. Blankart (2000) explains the stronger centralization in Germany, compared to Switzerland, after World War II by the missing direct democratic instruments at the federal level in Germany. He documents the centralization process by comparing Germany's Basic Law in 1949 with the one in 1999. With regard to taxation, for example, tax bases in 1949 were allocated exclusively to each of the three levels 
of government. In 1999, almost all the relevant taxes are under federal legislation, and separation of taxes is replaced by revenue sharing. This is reflected in a percentage of centralized taxes of 93.0 percent in 1995 compared to 61.2 percent in 1950. While, in Switzerland, a parliamentary system with two chambers exists that is similar to the one in Germany, there is a significant difference in the process of constitutional change. In the case of tax issues, for example, "since 1917, the citizens have been called no less than 23 times to vote on federal income and turnover taxes. Forty percent of the proposals have been declined in the first round" (Blankart 2000, p. 32). Accordingly, centralized taxes account for 47.4 percent in Switzerland in 1995, i.e. a much smaller proportion than in Germany (although both countries had similar levels in 1950: 60.1 percent in Switzerland and 61.2 percent in Germany).

The effect of direct democracy on government decentralization is also empirically documented for the lower levels of government. In an extension of the work on spending across US states from 1970-1999, Matsusaka (2004, chapter 4) studies how the initiative changes the division between state and local expenditure. While initiative states, on average, spend 13 percent less per capita at the state level than non-initiative states, they spend 4 percent more at the local level. The result is more decentralized spending patterns in states that adopt the initiative. Similar results are obtained for Swiss cantons in a panel over the period 1980 to 1998 (Schaltegger and Feld 2001). Rather than expenditure per capita, the proportion of cantonal expenditure in percent of total state and local spending is related to the development of the financial referendum. It is found that cantons with fewer obstacles to launching a budget referendum are less centralized with regard to expenditure, as well as revenue. The effect on expenditure is to a large extent due to more decentralized spending on education in more direct democratic cantons.

Direct democracy is not only affecting the process of fiscal centralization, but also spatial centralization. Martin and Wagner (1978) find that there are fewer municipal incorporations in US states, where direct democratic processes involve residents in incorporation decisions.

The problem of over-centralization also exists for other reasons (see Eichenberger 1994, Vaubel 1994) and is difficult to control. Rather than protect the federal system in the United States, the Supreme Court allowed a broad interpretation of activities assigned to the federal level that led to substantial centralization (Niskanen 1992). A referendum system, in contrast, is the constitutional provision that is most likely to protect a decentralized government. 


\section{Issues for Institutional Reform}

\section{Reforming Local Governance}

How can local governance be reformed and a new democratic federalism with strong direct democratic participation rights be introduced? We first discuss the chances and risks of implementing FOCJ. The emphasis is on conditions for successful implementation. FOCJ themselves might prepare political conditions for the adoption of direct democracy at higher government levels. An alternative gradual reform might start with the introduction of direct democracy. Once citizens have direct political participation possibilities, they can launch an initiative on whether to allow and to encourage the formation of FOCJ in the constitution. Progress in institutional reform is thus likely to be self-reinforcing.

\subsection{Implementation of FOCJ}

Our proposal is process-oriented. It is neither necessary nor possible to determine at the national level (or even at the European level) all the functions which should be provided by FOCJ and how these entities should be organized. The internal organization of a particular FOCUS lies in the competence of the communities and individuals who decide to establish such a jurisdiction. Nevertheless, it is possible to specify the conditions for FOCJ to emerge and to fulfill their tasks effectively. Thus, our approach follows the logic of constitutional economics which aims at designing beneficial decision processes without closely defining the outcomes (Buchanan and Tullock 1962, Mueller 1996).

One condition is crucial for FOCJ to work properly: They have to guarantee economic and political competition. Thus, economic markets in FOCJ have to be open; in particular, the four freedoms referring to the free movement of goods, services, and capital, and the free mobility of individuals have to be secured. At the same time, the political markets of FOCJ have to be competitive, i.e. the human rights and the fundamental democratic rights have to be secured to the full extent. This includes the right of the citizens to make use of the instruments of direct democracy.

Not only traditional governments, but also the governing bodies of FOCJ, pursue their own interests and tend to undermine competition and to build cartels or even monopolies. 
Therefore, the respective rules have to be monitored by a 'competition supervisory board'. This body has also to fix rules for determining the ceiling on entry and exit fees. If they are too high, mobility is hampered. However, such prices for mobility prove effective in preventing individuals from exploiting the redistributive policies in FOCJ. Regulative measures may also be necessary to enable FOCJ to supply public services effectively - as has been discussed above for the case of school-FOCJ. In such cases, it may be advantageous to declare membership in a FOCUS to be obligatory, and to fix minimum levels for the services to be supplied. The competition supervisory board must be given the competencies to step in if such regulations are violated. This board has to be empowered in a constitutional decision. It would be mistaken to delegate the monitoring of competition among FOCJ to the national bureaucracies which are interested in restricting FOCJ. Rather, an independent agency seems appropriate. A possible solution is a constitutional court (in the European Union the European Court). Although even such institutions tend to favor national at the cost of regional and local interests, they tend to decide less biasedly than national political institutions.

In light of the stiff resistance functional jurisdictions will meet, they will only emerge successfully if two conditions are met:

a) To found and to operate FOCJ must be a constitutionally guaranteed right - the fifth freedom, as we would like to call it. The newly founded political units must be allowed to operate as jurisdictions with (restricted) enforcement rights. The power to tax in order to finance a clearly specified service is the key to efficiency. However, this right of FOCJ will be disputed by other political units with which FOCJ will compete for the same tax base.

Principally, the communities (as the lowest level political units) as well as individuals in the constitution should be allowed to form FOCJ. However, depending upon the function to be fulfilled, membership may be restricted to the former. It is, e.g., well possible that individuals form a FOCUS which provides a special type of schooling; for other services, especially for those with stronger public good appeal, e.g., waste water treatment or local police, communities or parts of them are the "natural" agent. It is important to note that the decision as to which of those two classes a function belongs can be left to the local level itself. This decision should not be transferred to the European level.

b) Existing political units may not hinder the formation of FOCJ. As a most important consequence, the higher level political units have to appropriately reduce the taxes of 
those citizens who become members of a FOCUS or of various FOCJ providing governmental services. The competition supervisory board has to force the existing units to openly declare the cost, i.e. the tax prices of the various services they provide. These "tax price lists" can then serve to fairly rebalance the tax rate of the citizens who receive services from newly emerging FOCJ instead of from traditional political units. The existing governments' tendency to underrate the cost in order to minimize tax reductions to FOCJ members can be broken simply by demanding that the tax prices for a specific service not only serves to compensate exiting citizens, but also to tax former and newly entering service recipients. This rule makes the market for politics contestable. The potential existence of FOCJ is enough to compel all levels of government to give an account of the real cost of their services. However, it need not be said that existing political units will use all possible measures to impede the new competitors. The competition supervisory board has no easy job. Again, the constitutional court seems to be the appropriate institution to undertake this task. It could rely on the competencies of the audit office (the "Rechnungshof") to control the calculations of the tax prices. This latter institution has the necessary knowledge which has so far been wasted as audit offices are typically only allowed to formulate non-binding recommendations which are most often ignored by the political decision-makers.

\subsection{Precondition in Society for Direct Democracy}

There are many politico-economic obstacles to introducing political institutions that restrict the competence and influence of established interests. However, in societal crisis, or after a revolution (like in the former communist countries in Europe), there is a window of opportunity for institutional change and new basic rules for society. In order to successfully introduce direct democracy during these periods of time, a civic culture is necessary that facilitates the use of referendums and initiatives. It is impossible to successfully run directly democratic institutions where there is no adequate basis in society. One condition under which direct democracy ${ }^{27}$ works well is when there are strong cross-cutting cleavages (e.g. with respect to per capita income, religion, and culture or language). This guarantees that it is not always the same group of persons that finds itself in the minority and therefore feels exploited. As has also been emphasized, the citizens must have sufficient trust in the politicians that they actualize the referendum decision, and the politicians must trust that the 
citizens take reasonable decisions when voting on issues. This trust must develop over time and cannot simply be instilled from outside. Therefore, the "grand" solution of jumping from a representative democracy straight into a fully developed direct democracy is both unrealistic and undesirable. Rather, direct participation rights for the citizens should be gradually introduced $^{28}$, so that a learning process can take place between the citizens, parliament and government. The use of initiatives and referendums by the citizens is, however, also a major factor in raising civic culture, especially in the form of the trust citizens have in their government. Direct democracy thus helps to create the necessary conditions for its own smooth functioning, provided the learning effect indeed takes place.

\subsection{Gradual Introduction of Direct Democracy}

There are several ways in which directly democratic rights can be gradually introduced. Most of them restrict the application of direct democratic decision-making and constitute a considerable danger for direct democracy. Most importantly, the restrictions introduced may stay for good. In the case of several of the restrictions, this would amount to destroying the whole idea of citizens' participation in political decision-making. The institutions of direct democracy cannot develop their strengths. The outcome of politics would not correspond more closely to citizens' preferences than under a traditional representative system. Moreover, the citizens are unable to learn the special features of direct democracy properly. Five approaches for a gradual introduction are briefly discussed.

\section{Size of majority}

Passing a proposal in a popular vote may require a super majority, for instance two thirds of the participants. Alternatively, one may require a simple majority of the whole electorate, including those abstaining. Such quorums exist in Italy and many Transition Economies. In several of them, referendums received a majority of the votes cast, but not of the electorate. In Italy, these quorums led to the perverse situation that opponents of a referendum called people to abstain from voting and were thus undermining the institution of direct democracy as such.

\footnotetext{
${ }^{27}$ This condition is not only specific to direct democracies, but also holds for all types of democracy.

${ }^{28}$ To gradually introduce direct democratic elements in a political system dominated by the government may, however, induce the risk that the government on purpose undermines its functioning in order to "demonstrate" to the citizens that it cannot work.
} 
A strong restriction on popular initiatives and optional referendums is the number of signatures required. A balance between requiring a low number (and therefore having many referendums) and a high number (and therewith excluding citizens) is needed.

\section{Issue domain}

Some questions can be excluded from direct voting or can be protected with the use of qualified majorities, for fear of "irresponsible" or "uncontrollable" outcomes. One could restrict the domain in the following way:

- Basic parts of the constitution, such as those referring to human, political and civil rights, can be excluded. ${ }^{29}$

- Supposedly sensitive issues may be removed from citizens' voting. This may refer to problems relating to particular minorities, ethnic or religious groups, but also, for example, to the death penalty (as in Germany).

- Issues that are thought to be beyond the competence of the citizens. This may, for instance, be assumed to hold for economic problems, such as taxation. (In Germany, the recent proposal to introduce national referendums excluded tax issues from the very beginning).

These restrictions are probably most dangerous for a successful application of direct democratic decision-making, as they undermine the institution from the beginning. If only very unimportant issues are put to the vote, or if the number of signatures required for an initiative or optional referendum is far too high, the citizens cannot experience the advantages of direct democracy. On the other hand, the politicians can always claim that they gave direct democracy a chance, but that it did not work. In the case of tight restrictions, a vicious circle may develop. The way popular participation is introduced leads to unsatisfactory results and experiences, providing the opponents of direct democracy (in particular the politicians in power) with a good reason to introduce even more severe restrictions. Of course, under these circumstances, direct democracy cannot work.

\section{Decision level}

Direct democratic elements can be restricted by initially granting them only on a particular level of the state.

\footnotetext{
${ }^{29}$ Such restriction may make sense, also in fully developed direct democracies, but it should be noted that this is not the case in Switzerland. It should immediately be added that the Swiss voters have had no inclination to cheat where such basic rights are concerned.
} 
One possibility is to start at the local level, giving citizens the right to launch initiatives and vote in referendums in political communes. This allows the citizens to benefit from everyday or impacted information in order to form a reasoned opinion. Moreover, the issues are often of immediate relevance to the population. But this procedure only makes sense if the political communes have a sufficient amount of autonomy. Preferably, they should be able to decide both on taxes and public expenditures. Recently, in the case of EU member states, there have been introduced quite extensive referendum rights in some of the German Laender (in particular in Bavaria and the New Laender, see e.g. Luthardt und Waschkuhn 1997). ${ }^{30}$

Another possibility is to start at the national level, when major issues are at stake. This has indeed happened in several European countries, where the decisions of whether to join the European Union or to join one of the several treaties have been relegated to the citizens as a whole. As these decisions are of crucial importance, the citizens are well aware of their relevance and will certainly be inclined to participate in the vote.

The limitations on the levels at which elements of direct democracy are to be introduced make most sense. The rights for initiatives and referendums should first be introduced at the local level, and at the same time at the national level, and perhaps only later at the regional level. At the local level, the citizens tend to be well informed about the issues in question, while at the national level the decisions to be taken are of obvious importance. These are indeed the levels where direct democratic elements have been introduced in several transition economies, though only to a limited extent (Gross and Kaufmann 2002).

\section{Time}

The referendum process may be shaped by requiring a sufficient amount of time to pass between the start of an initiative or referendum process, the actual vote and the resulting decision becoming effective. This is a move towards the constitutional idea (e.g. Mueller 1996) of putting people behind the veil of uncertainty, and therefore inducing them to take a more "objective" position.

A more innovative idea is to proceed, as (many) parliaments do, namely to have a first, second and sometimes even a third reading of a law. In a direct democracy, one could first have an informative vote, and after sufficient time has elapsed to allow for a discussion of the outcome, a decisive vote could be cast.

\footnotetext{
${ }^{30}$ The referendum experience in other European countries is described in Gallagher and Uleri (1996).
} 


\section{Co-determination}

The citizens' decision may only become effective if it is supported by a corresponding vote in the parliament (and perhaps even in the two houses). This would, however, reduce referendums to a plebiscite. Another possibility would be to accord a veto right either to the citizens or to the parliament. One may also consider a double majority in the form of the popular vote and votes in the regions (cantons or states). This latter requirement applies, for instance, in Switzerland, where both the majority of all the Swiss voters, and the majority of the cantons, must approve a constitutional referendum.

\section{Concluding Remarks}

In most countries, at the local level, citizens perceive to have little power. But having power at the local level is essential for people's well-being. Many political decisions with the greatest and the most immediate impact on people's lives refer to the local level. Examples are the priorities of infrastructural services such as water, gas and electricity, police, schools, roads and social welfare. It is therefore important to improve citizens' possibilities to play a larger role in local politics. The goal must be to bring public decisions at the lower level closer to the preferences of the citizens.

The political institutions as they exist in most democracies in Europe are unable to provide such extended political participation possibilities. Therefore, additional institutions are to be considered. In our contribution, we advance two proposals.

First, we suggest more extensive direct political participation rights for the citizens going beyond voting for politicians who are supposed to represent their interests. We envisage two main institutions: referendums and initiatives. Each of these works differently and has different consequences on procedural utility as well as on outcomes. Referendums are designed to restrict the power of politicians and of public bureaucracy. When they take decisions which the citizens do not find to be in their interest, they can stop them. This power given to the citizens induces political decision makers to better consider how decisions affect the welfare of the citizens. Initiatives give citizens the power to become active themselves. They can bring their own ideas and wishes into the political process, which the politicians and public bureaucrats disregarded, overlooked, or who were not in their own interest. Both referendums and initiatives seek to induce policy changes, but do not directly intervene into the position of politicians. Further research could address recall. Recall, in contrast to 
initiatives and referendums, removes politicians, when the citizens feel that the person in question is unable, or does not want, to undertake policies in the interest of the local citizens.

Second, we propose to strengthen federalism, which in turn works to better fulfill local citizens' preferences. A new kind of institution is suggested, which addresses the biases in local public good supply produced by spillovers. The systematic biases can be overcome by adjusting the size of jurisdictions to the geography of problems. As the geography of problems differs markedly between the various functions, the activity of local supply must be differentiated according to function, and the size and the borders appropriately chosen. Functional, overlapping and competing jurisdictions (FOCJ) should be created which substitute for the presently existing All Purpose Jurisdictions. They promise to be an effective means to bring about a supply of public services better in line with the preferences of the population.

FOCJ integrate the first institutional proposal made by introducing elements of direct democracy and thus strengthening political competition.

The two institutional proposals made for strengthening the local power of citizens in the context of many European countries sound almost revolutionary. After all, in many European countries the decisions affecting local public supply are totally dictated by a far away centralized administration. But the proposals here made are certainly not utopian, or just theoretical possibilities. Indeed, direct democracy has proved to work well in several countries, above all the United States and Switzerland. Referenda have been increasingly used to decide about European issues, and sometimes also for national issues. The type of functional and overlapping federalism here proposed (FOCJ) has not been used in pure form, but elements are clearly visible in many places. An example is the European Union proceeding in different speeds. Some members of the EU desire a closer integration and have adopted e.g. the EURO and the Schengen agreements; other member countries do not want to integrate so closely and have opted out of these parts of common European policy.

In our contribution we have made a strong effort to strengthen our arguments with empirical evidence. Often it takes the form of economic estimates of parameters in multiple regressions bearing on the effects of particular variants of direct democracy and federalism.

We confidently conclude that the two institutions proposed for local goverance, direct democracy by referendums and initiatives, and functional and overlapping jurisdictions, are able to strengthen citizens' local power in a decisive and sustainable way. We are equally 
confident that the benefits in terms of procedures and outcomes would significantly raise the local population's well-being.

\section{Acknowledgement}

We thank Reiner Eichenberger for discussing with us many of the addressed issues on local governance. 


\section{References}

Advisory Commission on Intergovernmental Relations (ACIR) (1982). State and Local Roles in the Federal System. Report A-88. Washington D.C.: US Government Printing Office.

Advisory Commission on Intergovernmental Relations (ACIR) (1987) The Organization of Local Public Economies. Report A-109. Washington D.C.: US Government Printing Office.

Alt, James E. and David Dreyer Lassen (2003). The Political Economy of Institutions and Corruption in American States. Journal of Theoretical Politics 5(3): 341-365.

Ashworth, John, Bruno Heyndels and Carine Smolders (2002). Redistribution as a Local Public Good: An Empirical Test for Flemish Municipalities. Kyklos 55(1): 27-56.

Balch, George I. (1974). Multiple Indicators in Survey Research: The Concept of 'Sense of Political Efficacy'. Political Methodology 1: 1-43.

Barber, Benjamin R. (1984). Strong Democracy: Participatory Politics for a New Age. Berkeley: University of California Press.

Baumol, William J. and Hilda Baumol (1994). On the Economics of Musical Composition in Mozart's Vienna. Journal of Cultural Economics 18(3). 171-198.

Benz, Matthias and Alois Stutzer (2004). Are Voters Better Informed When They Have a Larger Say in Politics? Evidence for the European Union and Switzerland. Public Choice 119(1-2): 31-59.

Besley, Timothy and Stephen Coate (2000). Issue Unbundling via Citizens' Initiatives. Mimeo, Department of Economics, London School of Economics.

Blankart, Charles B. (1992). Bewirken Referenden und Volksinitiativen einen Unterschied in der Politik? Staatswissenschaften und Staatspraxis 3(4): 509-524.

Blankart, Charles B. (2000). The Process of Government Centralization: A Constitutional View. Constitutional Political Economy 11(1): 27-39.

Blöchliger, Hansjörg and René L. Frey (1992). Der schweizerische Föderalismus: Ein Modell für den institutionellen Aufbau der Europäischen Union? Aussenwirtschaft 47: 515-548.

Blomberg, S. Brock, Gregory D. Hess and Akila Weerapana (2004). The Impact of Voter Initiatives on Economic Activity. Forthcoming in European Journal of Political Economy.

Bohnet, Iris and Bruno S. Frey (1994). Direct-Democratic Rules: The Role of Discussion. Kyklos 47(3): 341-354.

Bowler, Shaun and Todd Donovan (1998). Demanding Choices: Opinion, Voting, and Direct Democracy. Ann Arbor: University of Michigan Press.

Bowler, Shaun and Todd Donovan (2002). Democracy, Institutions and Attitudes about Citizen Influence on Government. British Journal of Political Science 32(2): 371-390.

Brennan, Geoffrey and James M. Buchanan (1980). The Power to Tax. Analytical Foundations of a Fiscal Constitution. Cambridge: Cambridge University Press.

Brennan, Geoffrey and Alan P. Hamlin (2000). Democratic Devices and Desires. Cambridge: Cambridge University Press.

Buchanan, James M (1991). An American Perspective on Europe's Constitutional Opportunity. Cato Journal 10: 619-629.

Buchanan, James M. (1965). An Economic Theory of Clubs. Economica 32(1): 1-14.

Buchanan, James M. and Gordon Tullock (1962). The Calculus of Consent. Logical Foundations of Constitutional Democracy. Ann Arbor: University of Michigan Press. 
Butler, David and Austin Ranney (eds.) (1994). Referendums around the World. The Growing Use of Direct Democracy. Washington, D.C.: AEI Press.

Casella, Alessandra and Bruno S. Frey (1992). Federalism and Clubs: Towards an Economic Theory of Overlapping Political Jurisdictions. European Economic Review 36: 639-646.

Craig, Stephen C. and Michael A. Maggiotto (1982). Measuring Political Efficacy. Political Methodology 8: 85-110.

Cronin, Thomas E. (1989). Direct Democracy. The Politics of Initiative, Referendum and Recall. Cambridge, MA: Harvard University Press.

Curzon Price, Victoria and Jacques Garello (2003). Index of Fiscal Decentralisation: Methodology and Findings. Journal des Economistes et des Etudes Humaines 13(4): 441478.

Dahl, Robert A. (1956). A Preface to Democratic Theory. Chicago: University of Chicago Press.

Dahl, Robert A. and Edward Tufte (1973). Size and Democracy. Stanford, CA: Stanford University Press.

Deno, Kevin T. and Stephen L. Mehay (1985). Institutional Constraints on Local Jurisdiction Formation. Public Finance Quarterly 13: 450-463.

DiLorenzo, Thomas J. (1981). Special Districts and Local Public Services. Public Finance Quarterly 9: 353- 367.

Downs, Anthony (1957). An Economic Theory of Democracy. New York: Harper and Row.

Drèze, Jacques (1993). Regions of Europe: a Feasible Status, to be Discussed. Economic Policy 17: 266-307.

Dryzek, John S. (1990). Discursive Democracy: Politics, Policy and Political Science. Cambridge: Cambridge University Press.

Dubois, Philip L. and Floyd Feeney (1998). Lawmaking by Initiative: Issues, Options and Comparisons. New York: Agathon Press.

Eichenberger, Reiner (1994). The Benefits of Federalism and the Risk of Overcentralization. Kyklos 47(3): 403-420.

Eichenberger, Reiner (1999). Mit direkter Demokratie zu besserer Wirtschafts- und Finanzpolitik: Theorie und Empirie. In: Hans Herbert von Arnim (ed.) Adäquate Institutionen: Voraussetzung für "gute" und bürgernahe Politik? Schriftenreihe der Hochschule Speyer. Berlin: Duncker \& Humblot.

Eichenberger, Reiner and Bruno S. Frey (2002). Democratic Governance for a Globalized World. Kyklos 55(2): 265-88.

Eichenberger, Reiner and Angel Serna (1996). Random Errors, Dirty Information, and Politics. Public Choice 86: 137-156.

Epple, Dennis and Allan Zelenitz (1981). The Implications of Competition Among Jurisdictions: Does Tiebout Need Politics? Journal of Political Economy 89: 1197-1217.

European Constitutional Group (1993). A Proposal for a European Constitution. London.

Feld, Lars P. (2000). Steuerwettbewerb und seine Auswirkungen auf Allokation und Distribution: Ein Überblick und eine empirische Analyse für die Schweiz. Tübingen: Mohr Siebeck.

Feld, Lars P. and Bruno S. Frey (2002). Trust Breeds Trust: How Taxpayers Are Treated. Economics of Governance 3(2): 87-99. 
Feld, Lars P. and Gebhard Kirchgässner (2001). The Political Economy of Direct Legislation: Direct Democracy and Local Decision-Making. Economic Policy 0(33): 329-63.

Feld, Lars P. and John G. Matsusaka (2003). Budget Referendums and Government Spending: Evidence from Swiss Cantons. Journal of Public Economics 87(12): 2703-2724.

Feld, Lars P. and Marcel R. Savioz (1997). Direct Democracy Matters for Economic Performance: An Empirical Investigation. Kyklos 50(4): 507-538.

Finkel, Steven E. (1985). Reciprocal Effects of Participation and Political Efficacy: A Panel Analysis. American Journal of Political Science 29(4): 891-913.

Foster, Kathryn A. (1996). Specialization in Government, The Uneven Use of Special Districts in US Metropolitan Areas. Urban Affairs Review 31: 283-313.

Frey, Bruno S. (1983). Democratic Economic Policy. Oxford: Blackwell.

Frey, Bruno S. (1994). Direct Democracy: Politico-Economic Lessons from Swiss Experience. American Economic Review 84(2): 338-348.

Frey, Bruno S. (1997). A Constitution for Knaves Crowds Out Civic Virtues. Economic Journal 107(443): 1043-1053.

Frey, Bruno S., Matthias Benz and Alois Stutzer (2004). Procedural Utility: Not Only What, but also How Matters. Journal of Institutional and Theoretical Economics 160(3): 377401.

Frey, Bruno S. and Reiner Eichenberger (1999). The New Democratic Federalism for Europe: Functional Overlapping and Competing Jurisdictions. Cheltenham, UK: Edward Elgar.

Frey, Bruno S. and Lorenz Goette (1998). Does the Popular Vote Destroy Civil Rights? American Journal of Political Science 42(4): 1343-1348.

Frey, Bruno S. and Gebhard Kirchgässner (1993). Diskursethik, Politische Ökonomie und Volksabstimmungen. Analyse und Kritik 15(2): 129-149.

Frey, Bruno S., Marcel Kucher and Alois Stutzer (2001). Outcome, Process and Power in Direct Democracy. New Econometric Results. Public Choice 107(3-4): 271-293.

Frey, Bruno S. and Alois Stutzer (2000). Happiness, Economy and Institutions. Economic Journal 110(446): 918-38.

Frey, Bruno S. and Alois Stutzer (2002). Happiness and Economics. How the Economy and Institutions Affect Human Well-Being. Princeton, NJ: Princeton University Press.

Gallagher, Michael and Pier Vincenzo Uleri (eds.) (1996). The Referendum Experience in Europe. London: Macmillan.

Gamble, Barbara S. (1997). Putting Civil Rights to a Popular Vote. American Journal of Political Science 41(1): 245-269.

Gerber, Elisabeth R. (1997). The Populist Paradox: Interest Groups and the Promise of Direct Legislation. Princeton: Princeton University Press.

Gerber, Elisabeth R. and Simon Hug (2001). Legislative Response to Direct Legislation. In: Matthew Mendelsohn and Andrew Parkin (eds.). Referendum Democracy. Citizens, Elites and Deliberation in Referendum Campaigns. New York: Palgrave: 88-108.

Gold, Steven D. (1991). Interstate Competition and State Personal Income-Tax Policy in the 1980s. In: Daphne A. Kenyon and John Kincaid (eds.). Competition among States and Local Governments. Washington D.C.: Urban Institute Press: 205-217.

Gross, Andreas and Bruno Kaufmann (2002). IRI Europe Country Index on Citizen Lawmaking 2002. Amsterdam: IRI (Initiative and Referendum Insititute Europe). 
Habermas, Jürgen (1983). Diskursethik - Notizen zu einem Begründungsprozess. In: Jürgen Habermas (ed.) Moralbewusstsein und kommunikatives Handeln. Frankfurt: Suhrkamp: 53-125.

Hajnal, Zoltan L., Elisabeth R. Gerber and Hugh Louch (2002). Minorities and Direct Legislation: Evidence from California Ballot Proposition Elections. Journal of Politics 64(1): 154-177.

Haumann, Heiko (1991). Geschichte der Ostjuden. München: Deutscher Taschenbuch Verlag.

Hayek, Friedrich August von (1960). The Constitution of Liberty. Chicago: Chicago University Press.

Hirschman, Albert O. (1970). Exit, Voice and Loyalty. Cambridge, MA: Harvard University Press.

Inman, Robert P. and Daniel L. Rubinfeld (2000). Federalism. In: Boudewijn Bouckaert and Gerrit De Geest (eds.). Encyclopedia of Law and Economics. Publishers Edward Elgar and the University of Ghent.

URL: http://encyclo.findlaw.com/ [Query 17.09.2004]

Jones, Eric L. (1981). The European Miracle. Cambridge: Cambridge University Press.

Kirchgaessner, Gebhard (2001). The Effects of Fiscal Institutions on Public Finance: A Survey of the Empirical Evidence. CESifo Working Paper No. 617, Munich.

Kirchgaessner, Gebhard, Lars Feld and Marcel R. Savioz (1999). Die direkte Demokratie: Modern, erfolgreich, entwicklungs- und exportfähig. Basel et al.: Helbing and Lichtenhahn/ Vahlen/ Beck.

Kirchgässner, Gebhard und Werner W. Pommerehne (1996). Tax Harmonization and Tax Competition in the European Community: Lessons from Switzerland. Journal of Public Economics 60: 351-371.

Lane, Robert E. (1959). Political Life: Why and How People Get Involved in Politics. New York: Free Press.

Lane, Robert E. (1988). Procedural Goods in a Democracy. Social Justice Research 2(3): 177-192.

Lane, Robert E. (2000). The Loss of Happiness in Market Economies. New Haven and London: Yale University Press.

Lupia, Arthur (1994). Shortcuts versus Encyclopedias: Information and Voting Behavior in California Insurance Reform Elections. American Political Science Review 88(1): 63-76.

Lupia, Arthur and Mathew McCubbins (1998). The Democratic Dilemma: Can Citizens Learn What They Need to Know? New York: Cambridge University Press.

Luthardt, Wolfgang and Arno Waschkuhn (1997). Plebiszitäre Komponenten in der repräsentativen Demokratie: Entwicklungsstand und Perspektiven. In: Ansgar Klein und Rainer Schmalz-Bruns (Hrsg.). Politische Beteiligung und Bürgerengagement in Deutschland: Möglichkeiten und Grenzen. Baden-Baden: Nomos: 59-87.

Magleby, David B. (1984). Direct Legislation. Voting on Ballot Propositions in the United States. Baltimore and London: The John Hopkins University.

Mansbridge, Jane (1983). Beyond Adversary Democracy. Chicago: University of Chicago Press.

Martin, Dolores and Richard Wagner (1978). The Institutional Framework for Municipal Incorporation: An Economic Analysis of Local Agency Formation Commissions in California. Journal of Law and Economics 21(2): 409-425. 
Matsusaka, John G. (1995). Fiscal Effects of the Voter Initiative: Evidence from the Last 30 Years. Journal of Political Economy 103(2): 587-623.

Matsusaka, John G. (2004). For the Many or the Few. How the Initiative Process Changes American Government. Chicago: University of Chicago Press.

Mehay, Stephen L. (1984). The Effect of Governmental Structure on Special District Expenditures. Public Choice 44: 339-348.

Mueller, Dennis C. (1989). Public Choice II. Cambridge: Cambridge University Press.

Mueller, Dennis C. (1996). Constitutional Democracy. New York: Oxford University Press.

Nelson, Michael A. (1990). Decentralization of the Subnational Public Sector: An Empirical Analysis of the Determinants of Local Government Structure in Metropolitan Areas in the U.S. Southern Economic Journal 57: 443-457.

Niemi, Richard G., Stephen C. Craig and Franco Mattei (1991). Measuring Internal Political Efficacy in the 1988 National Election Study. American Political Science Review 85(4): 1407-1413.

Niskanen, William A. (1992). The Case for a New Fiscal Constitution. Journal of Economic Perspectives 6(2): 13-24.

Nuun, Samuel and Carl Schoedel (1997). Special Districts, City Governments, and Infrastructure. Spending in 105 US Metropolitan Areas. Journal of Urban Affairs 19: 5972 .

Oates, Wallace E. (1972). Fiscal Federalism . New York: Harcourt Brace Jovanovich.

Oates, Wallace E. (1991). Studies in Fiscal Federalism. Aldershot: Elgar.

Oates, Wallace E. (1999). An Essay on Fiscal Federalism. Journal of Economic Literature 37: 1120-1149.

Olson, Mancur (1969). The Principle of "Fiscal Equivalence": The Division of Responsibilities among Different Levels of Government. American Economic Review 59(2): 479-487.

Pak, Hung Mo (1995). Effective Competition, Institutional Choice and Economic Development of Imperial China. Kyklos 48: 87-103.

Pateman, Carol (1970). Participation and Democratic Theory. Cambridge: Cambridge University Press.

Pommerehne, Werner W. (1978). Institutional Approaches to Public Expenditure: Empirical Evidence from Swiss Municipalities. Journal of Public Economics 9(2): 225-280.

Pommerehne, Werner W. (1983). Private versus öffentliche Müllabfuhr: Nochmals betrachtet. Finanzarchiv 41: 466-475.

Pommerehne, Werner W. (1990). The Empirical Relevance of Comparative Institutional Analysis. European Economic Review 34(2-3): 458-469.

Pommerehne, Werner W. and Hannelore Weck-Hannemann (1996). Tax Rates, Tax Administration and Income Tax Evasion. Public Choice 88(1-2): 161-170.

Putnam, Robert D. (1993). Making Democracy Work. Princeton: Princeton University Press.

Putnam, Robert D. (2000). Bowling Alone: The Collapse and Revival of American Community. New York: Simon and Schuster.

Qian. Yingyi and Barry R. Weingast (1997). Federalism as a Commitment to Preserving Market Incentives. Journal of Economic Perspectives 11: 83-92. 
Rhode, Gotthold (1960). Staaten-Union und Adelsstaat: Zur Entwicklung von Staatsdenken und Staatsgestaltung in Osteuropa, vor allem in Polen/Litauen, im 16. Jahrhundert. Zeitschrift für Ostforschung 9: 185-215.

Riker, William H. and Peter C. Ordeshook (1973). An Introduction to Positive Political Theory. Englewood Cliffs, NJ: Prentice Hall.

Romer, Thomas and Howard Rosenthal (1978). Political Resource Allocation, Controlled Agendas, and the Status Quo. Public Choice 33(4): 27-43.

Romer, Thomas and Howard Rosenthal (1982). Median Voters or Budget Maximizers: Evidence from School Expenditure Referenda. Economic Inquiry 20(4): 556-78.

Rosenberg, Nathan and L.E. Birdzell (1986). How the West Grew Rich. The Economic Transformation of the Industrial World. London: I.B. Tauris.

Sandler, Todd and John T. Tschirhart (1980). The Economic Theory of Clubs: An Evaluative Survey. Journal of Economic Literature 18: 1488-1521.

Santerre, Rexford E. (1986). Representative versus Direct Democracy: A Tiebout Test of Relative Performance. Public Choice 48(1): 55-63.

Sartori, Giovanni (1987). The Theory of Democracy Revisited. Chatham, NJ: Chatham House.

Schaltegger, Christoph A. and Lars P. Feld (2001). On Government Centralization and Budget Referendums: Evidence from Switzerland. CESifo Working Paper No. 615, Munich.

Scharpf, Fritz (1970). Demokratietheorie zwischen Utopie und Anpassung. Konstanz: Universitätsverlag.

Schneider, Friedrich (1985). Der Einfluss der Interessengruppen auf die Wirtschaftspolitik: Eine empirische Untersuchung für die Schweiz. Bern: Haupt.

Sperber, Jonathan (1994). The European Revolutions 1848-51. Cambridge: Cambridge University Press.

Stutzer, Alois and Bruno S. Frey (2004). Political Participation and Procedural Utility: An Empirical Study. Forthcoming in European Journal of Political Research.

Thompson, Dennis F. (1970). The Democratic Citizen: Social Science and Democratic Theory in the Twentieth Century. New York: Cambridge University Press.

Tiebout, Charles M. (1956). A Pure Theory of Local Expenditure. Journal of Political Economy 64(5): 416-424.

Torgler, Benno (2003). Direct Democracy Matters: Tax Morale and Political Participation. In: National Tax Association Papers and Proceedings, Orlando, 2002. Washington: National Tax Association.

Tullock, Gordon (1967). Towards a Mathematics of Politics. Ann Arbor: University of Michigan Press.

Tullock, Gordon (1994). The New Federalist. Vancouver: Fraser Institute.

Vaubel, Roland (1994). The Political Economy of Centralization and the European Community. Public Choice 81(1-2): 151-190.

von Arnim, Hans Herbert (1988). Macht macht erfinderisch. Zürich and Osnabrück: Fromm.

Weede, Erich (1993). The Impact of Interstate Conflict on Revolutionary Change and Individual Freedom. Kyklos 46: 473-495. 
Weingast, Barry R. and Mark J. Moran (1983). Bureaucratic Discretion or Congressional Control? Regulatory Policymaking by the Federal Trade Commission. Journal of Political Economy 91(5): 765-800.

World Bank (2004). What is Empowerment?

URL: http://lnweb18.worldbank.org/ESSD/sdvext.nsf/68ByDocName/

WhatIsEmpowerment [Query 14.08.2004].

Zarkovic Bookman, Milica (1992). The Economics of Secession. New York: St. Martin's Press.

Zax, Jeffrey S. (1988). The Effects of Jurisdiction Types and Numbers on Local Public Finance. In Harvey S. Rosen (ed.). Fiscal Federalism: Quantitative Studies. Chicago: The University of Chicago Press: 79-106. 


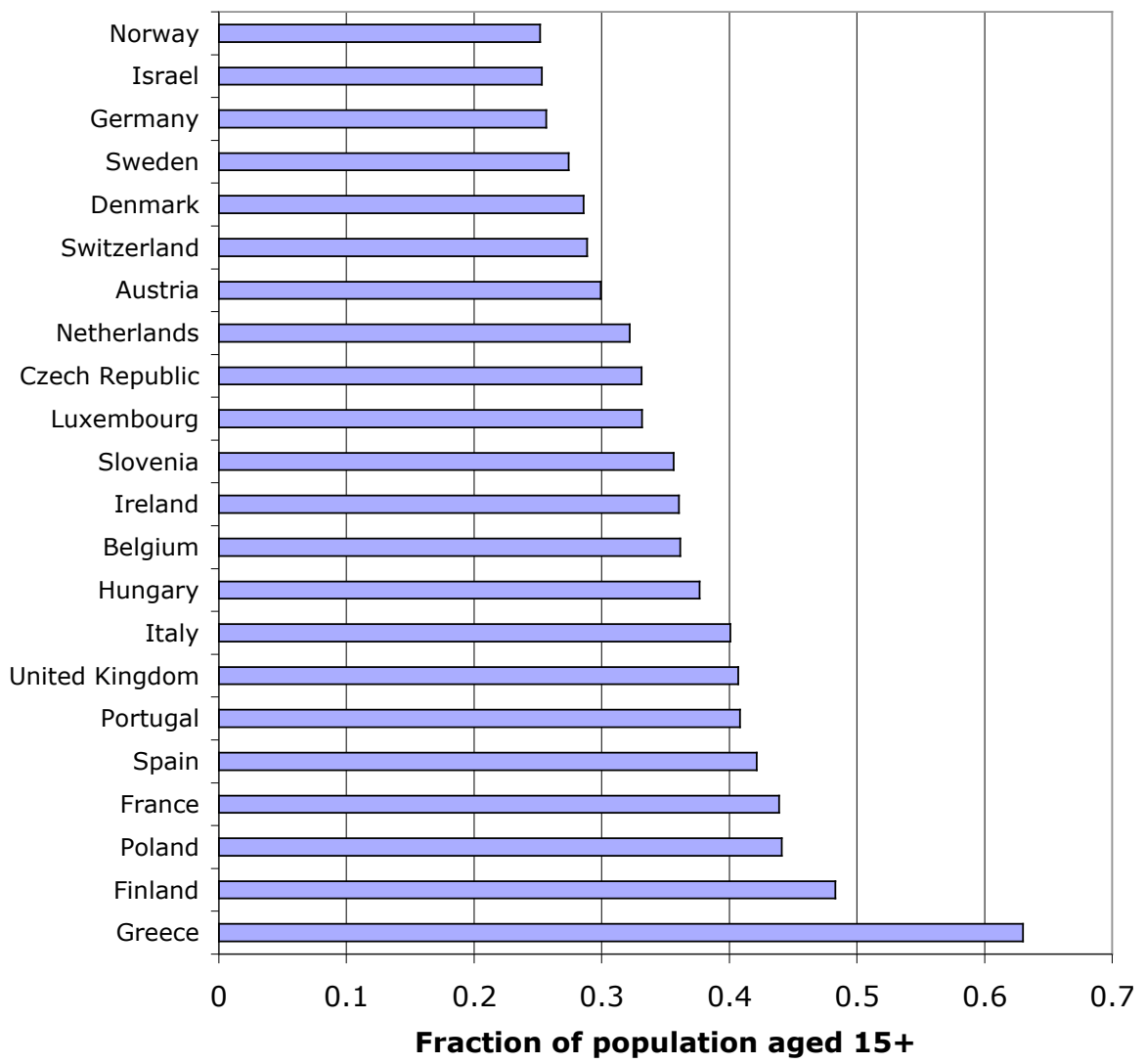

Figure 1: Politics is too complicated to understand

Source: European Social Survey, 2002. 


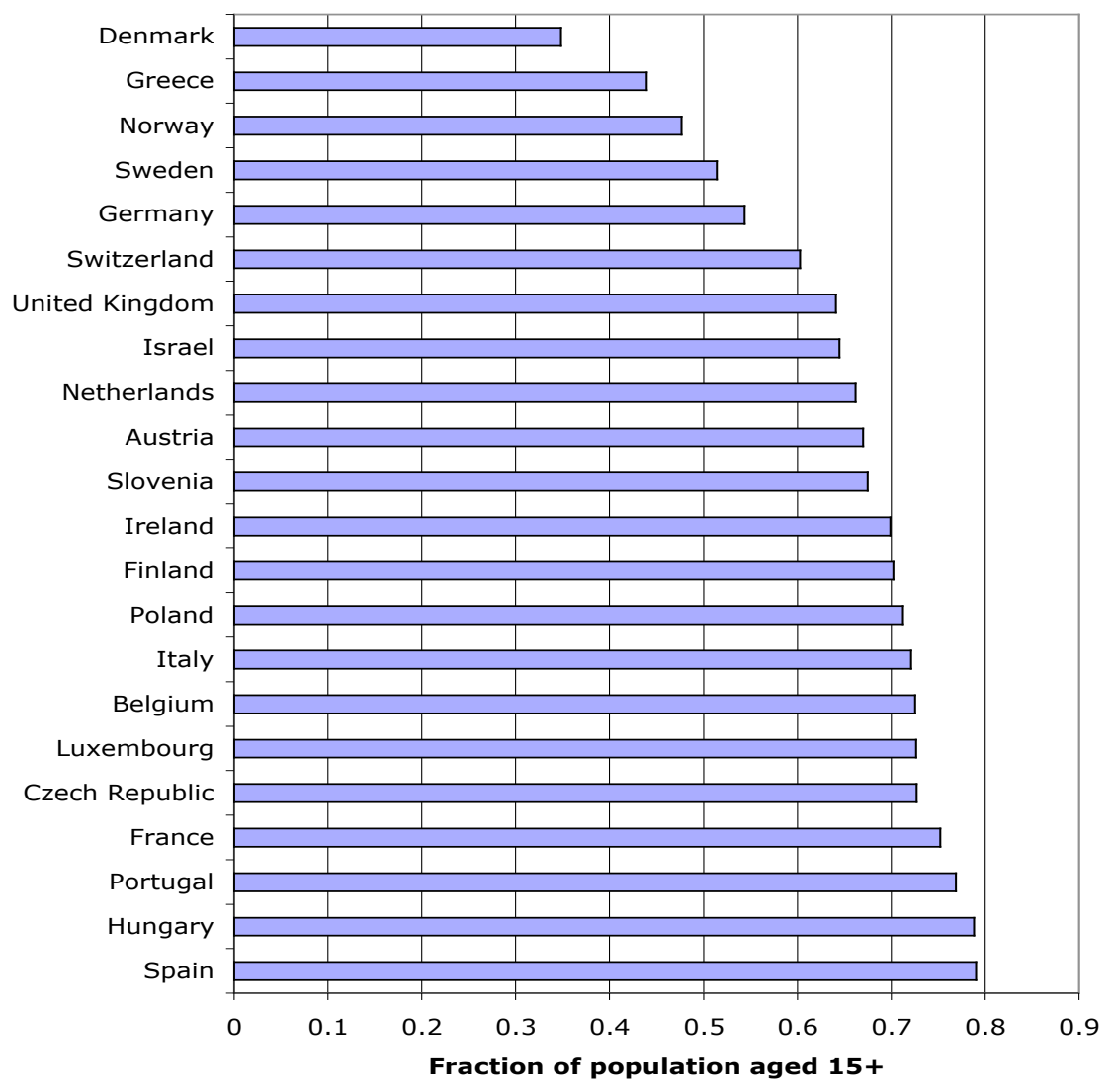

Figure 2: Not possible to take an active role in a group involved with political issues Source: European Social Survey, 2002. 


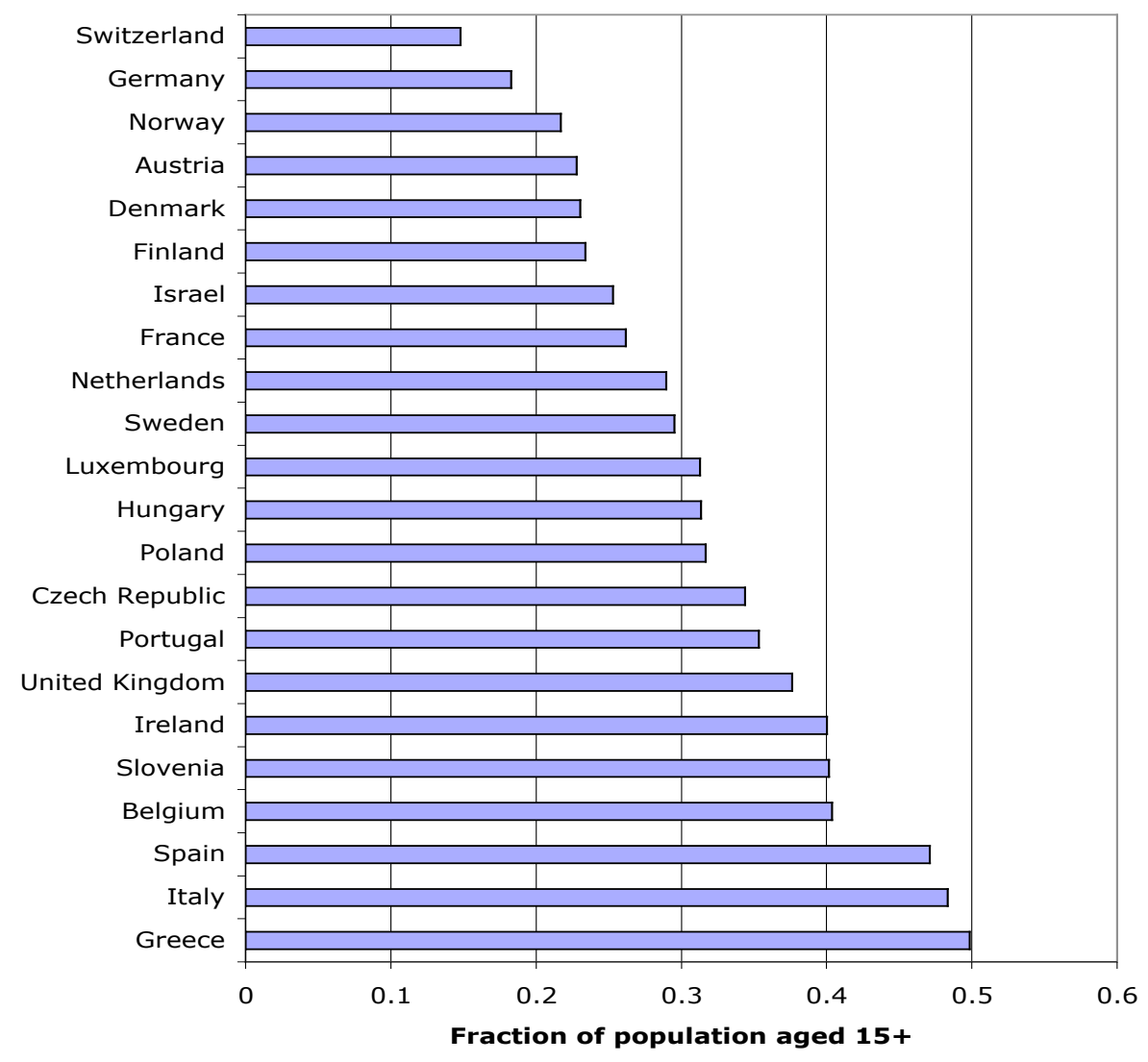

Figure 3: Discuss politics less often than once a month

Source: European Social Survey, 2002. 

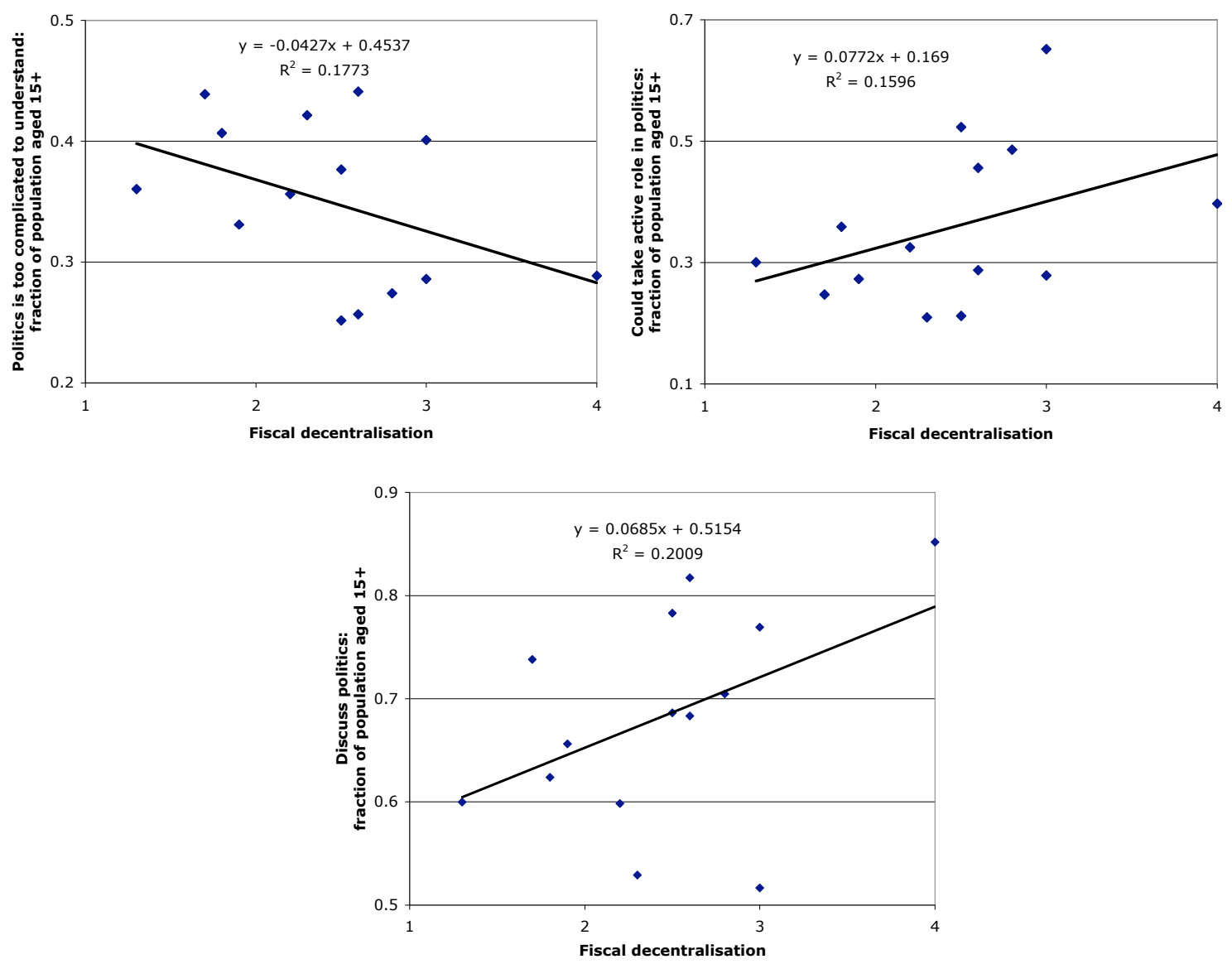

Figure 4: Fiscal decentralization and political empowerment Sources: European Social Survey, 2002; Curzon-Price and Garello (2003). 


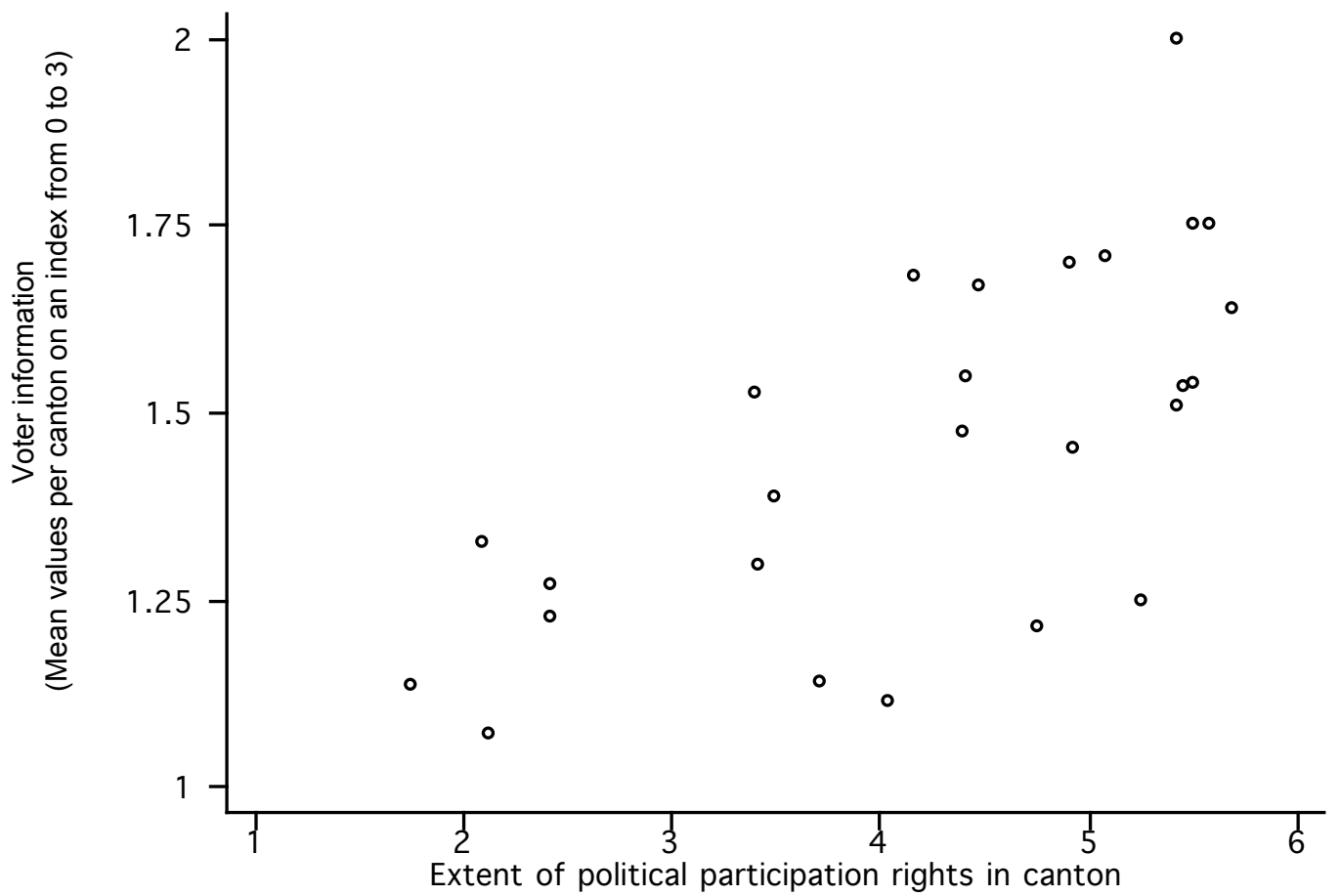

Figure 5: Correlation between Voter Information and Political Participation Rights in Swiss Cantons, 1995

Source: Benz and Stutzer (2004) based on Selects 1996. 